\title{
Aerosol-radiation-cloud interactions in a regional coupled model: the effects of convective parameterisation and resolution
}

\author{
Scott Archer-Nicholls ${ }^{1, a}$, Douglas Lowe ${ }^{1}$, David M. Schultz ${ }^{1}$, and Gordon McFiggans ${ }^{1}$ \\ ${ }^{1}$ Centre for Atmospheric Sciences, School of Earth, Atmospheric and Environmental Sciences, \\ University of Manchester, Manchester, UK \\ ${ }^{a}$ now at: National Centre for Atmospheric Research (NCAR), Boulder, CO, USA
}

Correspondence to: G. McFiggans (g.mcfiggans@manchester.ac.uk)

Received: 3 September 2015 - Published in Atmos. Chem. Phys. Discuss.: 13 October 2015

Revised: 23 March 2016 - Accepted: 22 April 2016 - Published: 4 May 2016

\begin{abstract}
The Weather Research and Forecasting model with Chemistry (WRF-Chem) has been used to simulate a region of Brazil heavily influenced by biomass burning. Nested simulations were run at 5 and $1 \mathrm{~km}$ horizontal grid spacing for three case studies in September 2012. Simulations were run with and without fire emissions, convective parameterisation on the $5 \mathrm{~km}$ domain, and aerosol-radiation interactions in order to explore the differences attributable to the parameterisations and to better understand the aerosol direct effects and cloud responses. Direct aerosol-radiation interactions due to biomass burning aerosol resulted in a net cooling, with an average short-wave direct effect of $-4.08 \pm 1.53 \mathrm{Wm}^{-2}$. However, around $21.7 \mathrm{Wm}^{-2}$ is absorbed by aerosol in the atmospheric column, warming the atmosphere at the aerosol layer height, stabilising the column, inhibiting convection, and reducing cloud cover and precipitation. The changes to clouds due to radiatively absorbing aerosol (traditionally known as the semi-direct effects) increase the net short-wave radiation reaching the surface by reducing cloud cover, producing a secondary warming that counters the direct cooling. However, the magnitude of the semi-direct effect was found to be extremely sensitive to the model resolution and the use of convective parameterisation. Precipitation became organised in isolated convective cells when not using a convective parameterisation on the $5 \mathrm{~km}$ domain, reducing both total cloud cover and total precipitation. The SW semi-direct effect varied from $6.06 \pm 1.46$ with convective parameterisation to $3.61 \pm 0.86 \mathrm{Wm}^{-2}$ without. Convective cells within the $1 \mathrm{~km}$ domain are typically smaller but with greater updraft velocity than equivalent cells in the $5 \mathrm{~km}$ domain, reducing the proportion of the domain covered by cloud in all scenar-
\end{abstract}

ios and producing a smaller semi-direct effect. Biomass burning (BB) aerosol particles acted as cloud condensation nuclei $(\mathrm{CCN})$, increasing the droplet number concentration of clouds. However, the changes to cloud properties had negligible impact on the net radiative balance in either domain, with or without convective parameterisation. The sensitivity to the uncertainties relating to the semi-direct effect was greater than any other observable indirect effects. Although the version of WRF-Chem distributed to the community currently lacks aerosol-cloud interactions in parameterised clouds, the results of this study suggest a greater priority for the development is to improve the modelling of semi-direct effects by reducing the uncertainties relating to the use of convective parameterisation and resolution before WRF-Chem can reliably quantify the regional impacts of aerosols.

\section{Introduction}

Aerosol particles in the atmosphere have a major impact on global climate but also contribute some of the greatest uncertainties due to their heterogeneous distribution and complicated interactions with clouds and radiation (IPCC, 2013). The aerosol-radiation interactions, commonly known as the direct effects, tend to result in a scattering of solar radiation and cooling of the Earth's surface (Haywood and Boucher, 2000; Zhang et al., 2008; Chand et al., 2009). However, many aerosol particles also contain black carbon (BC), which absorbs radiation across a wide spectrum of wavelengths (Bond et al., 2013). Whether an absorbing aerosol layer has a net cooling or warming effect, as seen from the top of the atmo- 
sphere (TOA), depends greatly on whether it is over a lowor high-albedo surface (Haywood et al., 1995; Haywood and Boucher, 2000).

As well as their direct interactions with radiation, aerosol particles can perturb the Earth's radiative budget through their impacts on clouds (Lohmann and Feichter, 2005; Rosenfeld et al., 2008; IPCC, 2013; Possner et al., 2015). The absorption of radiation changes atmospheric stability and circulation and therefore cloud formation (IPCC, 2013). These adjustments by the climate system are traditionally known as the semi-direct effects (Hansen et al., 1997; Ackermann et al., 2000). The sign and magnitude of the semi-direct radiative forcings are sensitive to whether the aerosol layer is over land or sea (Allen and Sherwood, 2010) and to the vertical distribution, depending on whether the aerosol layer is below, at or above cloud height (Johnson et al., 2004; Koch and Del Genio, 2010). In addition, aerosol particles act as cloud condensation nuclei (CCN; Andreae et al., 2004; McFiggans et al., 2006; Hennigan et al., 2012). Polluted clouds have an increased cloud droplet number, resulting in the first indirect effect, whereby brighter clouds reflect more radiation back to space (Twomey, 1974; Lohmann and Feichter, 2005; Possner et al., 2015). An increased droplet number may further perturb cloud lifetime, height and the ability to initiate precipitation (Andreae and Rosenfeld, 2008; Chen et al., 2011). The addition of aerosol particles can either inhibit or enhance cloud formation: a small increase in $\mathrm{CCN}$ above pristine conditions in deep convective clouds causes more droplets to reach supercooled levels, increasing the amount of latent heat release and invigorating convection (Rosenfeld et al., 2008; Pöschl et al., 2010; Possner et al., 2015). Rosenfeld et al. (2008) estimate the maximum invigoration point to be at a $\mathrm{CCN}$ concentration of $0.4 \%$ supersaturation $\left(\mathrm{CCN}_{0.4}\right)$ of approximately $1200 \mathrm{~cm}^{-3}$. Further increases in $\mathrm{CCN}$ result in the direct radiative effects dominating, which cool the surface and inhibit convection.

The primary tool for estimating aerosol particles' impact on climate has been the use of global climate models (IPCC, 2013, and references therein). However, horizontal grid spacing is typically in the order of a degree, meaning most clouds are smaller than a grid box and must be parameterised, introducing uncertainties as to how the system responds to forcings by aerosol particles (Johnson, 2004; Ghan et al., 2006; Lohmann and Ferrachat, 2010). For example, the magnitude and sign of the semi-direct effects show strong sensitivity to the cloud parameterisation used (Cook et al., 2004).

At the other end of the resolution spectrum, large eddy simulation (LES) models are capable of explicitly resolving clouds with detailed bin microphysics at grid spacings in the order of 10-100 m. Although LES models can only be used over small areas, often with idealised boundary conditions, they are useful to gain insight into how aerosols affect clouds and are known to reproduce more realistic behaviour than the parameterisations used in global models (Romakkaniemi et al., 2009; Chen et al., 2011). Johnson (2004) compared a single-column model, equivalent to a cloud parameterisation used in global models, with an LES model and found the semi-direct effect over a stratocumulus deck was 5 times stronger in the LES simulation, implying deficiencies in the ability of global models to parameterise aerosol-cloud interactions.

The need to better understand the impact of aerosolradiation-cloud interactions on a regional scale has driven the development of "online" models with "full" couplings between the air quality and meteorological components (Baklanov et al., 2011; Grell and Baklanov, 2011; Baklanov et al., 2014). The Weather Research and Forecasting model with Chemistry (WRF-Chem) is one such model (Grell et al., 2005; Fast et al., 2006). Unlike in offline chemical transport models, the gas-phase chemical and aerosol fields are transported using the same time step and physical parameterisations as the core numerical weather prediction model. By linking aerosol optical properties to the radiation scheme and CCN potential to the microphysics scheme, feedbacks between aerosols and meteorology can be modelled (Chapman et al., 2009; Barnard et al., 2010; Zhao et al., 2011). However, the publicly available version of WRF-Chem is currently limited by having no aerosol-cloud interactions in parameterised convective clouds, and no linkages exist in the model between aerosol particles and ice nuclei (Chapman et al., 2009). Studies into indirect effects with WRFChem have therefore tended to focus on marine stratocumulus, which can be resolved at coarser resolutions (e.g. Yang et al., 2011; Saide et al., 2012).

As computing resources have improved, WRF-Chem has been increasingly run at fine resolutions with horizontal grid spacings of less than $10 \mathrm{~km}$ (e.g. Grell et al., 2011; Wu et al., 2011a, b; Saide et al., 2012; Shrivastava et al., 2013; Fast et al., 2014). These scales (commonly known as the "grey zone") are challenging to model because the assumptions behind the deep-convective parameterisations begin to break down, but the model cannot be expected to resolve all convection explicitly (Hong and Dudhia, 2012). The Grell-3-D convective parameterisation has in part been developed to be used over these intermediate horizontal resolutions by allowing "subsistence spreading" to neighbouring grid cells (Grell and Freitas, 2014). However, it is currently unclear how effectively cloud responses to aerosol in the grey zone are simulated with this parameterisation. Through further nesting, WRF-Chem can be run on scales where no cumulus parameterisation should be used ( $\Delta x \lesssim 4 \mathrm{~km})$, bridging the gap between global climate and LES models to explicitly resolve aerosol-cloud interactions in warm convective clouds. However, even on these fine scales questions remain as to how well some structures, such as shallow cumulus clouds, are simulated (Hong and Dudhia, 2012).

This modelling study investigates how regional aerosolradiation-cloud interactions are captured in WRF-Chem, using a period during the South American Biomass Burning Analysis (SAMBBA) project as an example. The modelled 
aerosol direct, semi-direct and indirect effects are calculated for several different model configurations. These cover two different horizontal grid spacings and include running with and without a convective parameterisation and with and without fire emissions. Using these results, the uncertainties in representing these processes within models, and the difficulties in making accurate predictions, are illustrated. Knowledge about how these processes interact with, and feed back to, each other and the general model configuration is important for determining the best manner in which to run models such as WRF-Chem. How these processes, and the feedbacks between them, are configured varies between different limited-area coupled models or global climate models. This kind of detailed analysis therefore has to be done for each model (rather than assuming that certain interactions between processes will all behave in the same manner in every model). This study is intended to show how these processes interact within WRF-Chem and provide impetus for further developments to improve the realism of these simulations, as well as consistency through the different model scales.

The test case used is a region of Brazil known to be heavily polluted by biomass burning aerosol (BBA) during the dry season. The aerosol haze layer is characterised as being highly radiatively absorbing (single scattering albedo between 0.8 and 0.9 ), optically thick (aerosol optical depths between 0.4 and 1.2 ), vertically elevated to cloud level through biomass burning plume processes and efficient at acting as CCN (Reid et al., 2005a, b; Martin et al., 2010; ArcherNicholls et al., 2015). The high aerosol concentrations in this region should provide a strong signal for aerosol-radiation and aerosol-cloud interactions for the study.

WRF-Chem has been previously used to investigate the impact of BBA on weather and climate. For example, Grell et al. (2011) found a modest improvement to the modelled representation of the vertical temperature profile when biomass burning emissions and aerosol feedbacks were included in runs over Alaska. Zhang et al. (2014) evaluated the direct radiative effects of BBA over northern sub-Saharan Africa and found that impact vary widely depending on the emission inventory used. Wu et al. (2011b) ran simulations over Brazil at 36 and $4 \mathrm{~km}$ horizontal grid spacing, with no convective parameterisation on the $4 \mathrm{~km}$ domain. They found BBA to inhibit afternoon convection over the domain, reducing daytime precipitation but increasing it at night, albeit with a net decrease in precipitation. The 36 and $4 \mathrm{~km}$ simulations were qualitatively similar.

This paper follows on from Archer-Nicholls et al. (2015), which aimed to characterise the BBA population in Brazil in the 2012 fire season. The model output was evaluated against remote sensing and in situ aircraft measurements from the SAMBBA campaign. The model fields from Archer-Nicholls et al. (2015) are used to drive initial and boundary conditions for two nested domains with 5 and $1 \mathrm{~km}$ horizontal grid spacing in this study. The $5 \mathrm{~km}$ domain was chosen to be within the grey zone in order to probe how the WRF-Chem simu-
Table 1. Eight-bin MOSAIC size grid.

\begin{tabular}{ll}
\hline Bin number & Particle dry diameter $(\mathrm{nm})$ \\
\hline 1 & $39.0625-78.125$ \\
2 & $78.125-156.25$ \\
3 & $156.25-312.5$ \\
4 & $312.5-625$ \\
5 & $625-1250$ \\
6 & $1250-2500$ \\
7 & $2500-5000$ \\
8 & $5000-10000$ \\
\hline
\end{tabular}

lates aerosol interactions and impacts, while the $1 \mathrm{~km}$ domain has no need for a convective parameterisation. Several runs were conducted using different emission scenarios and options for aerosol-radiation interactions to separate the instantaneous radiative effects of the aerosol from aerosol-cloud interactions. The sensitivity of the semi-direct and indirect effects to convective parameterisation and horizontal resolution is also investigated. Due to the limited area and duration of the model runs, simulating the full changes to circulation as a result of the forcings is beyond the scope of the current study, and so only short-term responses are investigated.

\section{Model description}

This study uses WRF-Chem version 3.4.1 with changes made to use the Model for Simulating Aerosol Interactions with Chemistry (MOSAIC) aerosol scheme (Zaveri et al., 2008) and the updated Carbon Bond Mechanism (CBM-Z) gasphase chemistry scheme (Zaveri and Peters, 1999) and fire emissions from the Brazilian Biomass Burning Emissions Model (3BEM) (Longo et al., 2010), as described by ArcherNicholls et al. (2015). As an online coupled model, the meteorological, transport, chemical and aerosol components are integrated at the same time. Forcings from the chemical and aerosol fields can feed back to the meteorology and vice versa (Grell et al., 2005). These feedbacks primarily occur through the aerosol-radiation interactions and aerosol particles acting as $\mathrm{CCN}$ to influence cloud properties. A robust approach to describe the aerosol population and their interactions with clouds and radiation is therefore needed.

\subsection{The MOSAIC aerosol mechanism}

The MOSAIC mechanism is a sectional scheme, whereby the aerosol size distribution is described as a set of discrete size bins (Zaveri et al., 2008). This study uses eight size bins across a range of $39 \mathrm{~nm}$ to $10 \mu \mathrm{m}$, as shown in Table 1. MOSAIC carries five inorganic ions, which can react in the aqueous phase and partition with the gas-phase mechanism, plus three unreactive primary aerosol species: black carbon (BC), particulate organic matter (POM) and other inorganics (OIN; 
Fast et al., 2006; Zaveri et al., 2008). All chemical components within each size bin are assumed to be internally mixed (i.e. evenly mixed within the same particles), whilst different size bins are assumed to be externally mixed (Zaveri et al., 2008).

The version of MOSAIC used in this study does not carry secondary organic aerosol (SOA). Current conventional treatments are unable to capture frequently observed SOA behaviour, such as the formation of sufficient mass from known precursors or the oxygen to carbon ratio $(\mathrm{O}: \mathrm{C})$ of the material. Alternative treatments are available, such as the volatility basis set (VBS; Donahue et al., 2011; Shrivastava et al., 2011, 2013), but remain unconstrained for the current application. In particular, it is unclear how previously used treatments can capture behaviour such as that summarised in the meta-analysis of Jolleys et al. (2012), which described the lack of increase in organic mass from biomass burning sources but an increase in $\mathrm{O}: \mathrm{C}$. Ongoing developments of the VBS are in progress to explore mechanisms by which observed organic aerosol (OA) behaviour is best captured, but they are beyond the scope of the current work. However, it is expected that the current approach will reasonably capture the OA mass and hence the POM : $\mathrm{BC}$ ratio.

Whilst uncertainties in the model representation of aerosol composition (particularly POM : BC ratio), size distribution and optical properties can result in uncertainties in predicted radiative forcings (Matsui et al., 2013; Kodros et al., 2015), an investigation of these uncertainties is beyond the scope of the current study. Notwithstanding the discussed limitations, using a sectional representation of aerosol provides a reasonably robust approach for calculating the aerosol optical properties and interactions with clouds, as described below.

\subsection{Calculation of aerosol optical properties}

Within MOSAIC, each aerosol chemical component has its own associated complex refractive index, with $\mathrm{BC}$ being the most absorbing (Barnard et al., 2010). The overall complex refractive index is calculated for each bin using a mixing rule to approximate the internal structure of the aerosol particles. Assuming an internal mixture of $\mathrm{BC}$ with other components can result in an overestimation of the particle absorption cross section (Bond and Bergstrom, 2006). Describing particles using a spherical BC core with other component shells (a "shell-core" mixing rule) is often regarded as the most robust approach for 3-D model applications (Bond et al., 2006; Bond and Bergstrom, 2006; Barnard et al., 2010; Matsui et al., 2013) but was found to be unstable in WRFChem version 3.4.1. In this study, the Maxwell-Garnett mixing rule is used, whereby aerosol particles are assumed to be made up of randomly distributed spheres of BC throughout a mixture of all other components (Bohren and Huffman, 1983, chapter 8). The Maxwell-Garnett rule does not suffer from the anomalous absorption enhancement of the internal mixing rule (Bond and Bergstrom, 2006).
Mie calculations are used to calculate the intermediate optical properties for each bin, which are summed over all size bins to give the bulk extinction coefficient $\left(b_{\text {ext }}\right)$, scattering coefficient $\left(b_{\mathrm{s}}\right)$, single scattering albedo $\left(\omega_{0}=b_{\mathrm{s}} / b_{\text {ext }}\right)$ and asymmetry factor $(g)$. Each of these variables are functions of the size parameter $(x=2 \pi r / \lambda)$, where $\lambda$ is the wavelength of light and $r$ is the wet radius at the centre of the aerosol bin (Fast et al., 2006). To save on computation, the methodology of Ghan et al. (2001) is employed to carry out the full Mie calculations only on the first call to the subroutine. The net radiative impacts are calculated by passing the bulk optical properties of the aerosol layer to the radiative transfer parameterisation. This study uses the rapid radiative transfer model (RRTMG, Mlawer et al., 1997; Iacono et al., 2000) for both short-wave (SW) and long-wave (LW) radiation following Zhao et al. (2011). Optical properties in the SW are calculated at four wavelengths $(\lambda=300,400,600$ and $1000 \mathrm{~nm})$. For intermediate $\lambda, b_{\text {ext }}$ is estimated using an Ångström coefficient, whereas $\omega_{0}$ and $g$ are linearly interpolated. A full description of the optical property calculations is given by Fast et al. (2006) and Barnard et al. (2010).

\subsection{Calculation of aerosol-cloud interactions}

A key process in simulating aerosol-cloud interactions is the activation of $\mathrm{CCN}$ to form cloud droplets. The Köhler et al. (1936) theory describes the equilibrium state of an aerosol particle, assumed to be an aqueous salt solution, with ambient water vapour. The critical supersaturation $\left(S_{\text {crit }}\right.$, defined as the supersaturation at which an aerosol particle becomes activated to form a cloud droplet) depends upon both aerosol size and composition. Aerosol particles that are larger and/or more hygroscopic are activated more easily and so have a lower $S_{\text {crit }}$ (McFiggans et al., 2006). Within MOSAIC, $S_{\text {crit }}$ is calculated for each bin using a mass-weighted average of the associated hygroscopicity of all chemical components within that bin using the methodology of Abdul-Razzak and Ghan (2002).

The primary driver of cloud droplet activation is the updraft velocity $(w)$ : air parcels with higher $w$ reach higher maximum supersaturations $\left(S_{\max }\right)$. All particles with $S_{\text {crit }}<$ $S_{\max }$ will be activated, whereas those with $S_{\text {crit }}>S_{\max }$ remain unactivated within clouds and are known as interstitial aerosols (Chapman et al., 2009). Greater CCN concentration increases the total particulate surface area, increasing competition for condensable water and reducing $S_{\max }$. Subgrid variation in updraft velocity $(w)$ is described using a Gaussian distribution function, with a minimum spread of $\sigma_{w}=0.1 \mathrm{~m} \mathrm{~s}^{-1}$ (Ghan et al., 1997). The number and mass fraction of activated $\mathrm{CCN}$ in each aerosol bin can then be calculated by comparing $S_{\max }$ with $S_{\text {crit }}$ at the sectional limits of each bin (Abdul-Razzak and Ghan, 2002). Inversely, this method can also estimate the $\mathrm{CCN}$ concentration at given supersaturations. WRF-Chem carries six diagnostic variables showing the concentration of particles that can potentially 
activate at given supersaturations of $0.02,0.05,0.1,0.2,0.5$ and $1 \%\left(\mathrm{CCN}_{0.02}, \mathrm{CCN}_{0.05}, \mathrm{CCN}_{0.1}, \mathrm{CCN}_{0.2}, \mathrm{CCN}_{0.5}\right.$ and $\mathrm{CCN}_{1.0}$ respectively).

Recently, Simpson et al. (2014) have shown that the Abdul-Razzak and Ghan (2000) parameterisation produces unrealistic activated fractions of aerosol in some atmospherically relevant conditions when compared with an explicit bin-resolving cloud-parcel model. The scheme was shown to overpredict activation when the aerosol population median diameter was $\gtrsim 300 \mathrm{~nm}$. However, given that the median diameter in BBA populations is generally between 100 and $150 \mathrm{~nm}$ (Janhall et al., 2010), this behaviour should not negatively impact the simulations in this study.

To model the indirect effects the cloud activation scheme needs to be coupled with a double-moment microphysical parameterisation that carries both number and mass loadings for hydrometeors. Following Yang et al. (2011), the double-moment Morrison et al. (2005, 2009) parameterisation has been coupled with MOSAIC aerosol, such that the number concentration of liquid droplets is controlled by activated aerosol. The couplings are currently only for warmcloud processes, with no direct links between aerosol and ice nuclei (Chapman et al., 2009). A major limitation in using WRF-Chem to assess aerosol-cloud interactions is that the couplings are only computed in explicitly resolved clouds, not convective clouds simulated by the cumulus parameterisation (Chapman et al., 2009; Yang et al., 2011). Work is being conducted to include aerosol interactions with parameterised cloud (e.g. Grell and Freitas, 2014; Berg et al., 2015). However, these developments were not available for general WRF-Chem release at the time of this study.

Wet removal is one of the main sinks of particulate mass. Wet scavenging of interstitial and activated aerosol, both in and below cloud, are parameterised following scavenging efficiencies described by Slinn (1984). Wet deposition of MOSAIC aerosol species is treated for explicitly resolved clouds via precipitation of cloud-phase aerosol, and impactioninterception wet scavenging of aerosol below cloud. For parameterised convective clouds there is washout of a fraction of aerosol species in the same grid cell as the parameterised cloud (based on the precipitation rate from that cell, without dependence on aerosol size or composition), but no belowcloud wet scavenging. Once aerosol particles are attached to hydrometeors, they are assumed to be immediately deposited out of the atmosphere, without the possibility of resuspension following evaporation (for more details see Yang et al., 2015).

In deep convective clouds, secondary activation of aerosol has been observed (Heymsfield et al., 2009) and modelled (e.g. Segal et al., 2003; Yang et al., 2015), whereby further interstitial aerosol particles are activated above cloud base due to supersaturation not being fully offset by droplet growth, as hydrometeors are scavenged in the cloud column. This is a process unrepresented in the current model setup, as the Abdul-Razzak and Ghan (2002) parameterisation assumes all activation at cloud base. If secondary activation were included in the model, it would primarily act to increase the efficiency with which aerosol is scavenged from cloud and reduce the amount of aerosol transported to the mid and upper troposphere (Yang et al., 2015). However, representing this process is challenging on this scale of the model, without bin microphysics or fully resolved updraft velocities. Use of the aerosol-aware Kain-Fritsch parameterisation (Berg et al., 2015) could enable consideration of this process in parameterised clouds for future studies.

\section{Experimental methods}

This section describes the model setup and rationale for the experiments conducted for this study. The objective is to probe the response of the WRF-Chem model to aerosolradiation and aerosol-cloud interactions across a range of scales and meteorological conditions. The high levels of elevated, highly absorbing aerosol over Amazonia during the dry-to-wet season transition provide a good test bed for the experiments by producing a strong signal of aerosol forcings. Several scenarios were constructed to isolate the various aerosol impacts, as described below.

\subsection{Domain setup and methods}

Archer-Nicholls et al. (2015) described a parent domain run for the whole of September 2012 with $226 \times 196$ grid cells at $25 \mathrm{~km}$ horizontal grid spacing covering most of South America, 41 vertical levels up to $50 \mathrm{hPa}$ with 18 levels within the lowest $3 \mathrm{~km}$ and a Lambert conformal conic projection. The meteorological input and boundary conditions were driven by the operational, deterministic (high-resolution) 1-day forecasts of the European Centre for Medium-Range Weather Forecasts (ECMWF, http://www. ecmwf.int/). Chemical and aerosol boundary conditions were derived from the MACC-II reanalysis (Monitoring Atmospheric Composition and Climate - Interim Implementation; Hollingsworth et al., 2008; Flemming et al., 2013).

This study focuses on the output of two nested domains, with 5 and $1 \mathrm{~km}$ grid spacing respectively. The location of the $5 \mathrm{~km}$ nest encompasses a region of high aerosol optical depths (AODs) over Rondônia state. The $1 \mathrm{~km}$ domain is positioned over a region with high AODs, flat topography and heavy precipitation on 18 September 2012. A map of all three domains is shown in Fig. 1. The nests were run for three $36 \mathrm{~h}$ case study periods with contrasting meteorological conditions, starting at 00:00 UTC on 14, 18 and 23 September 2012 respectively (where local time: UTC-4h). The ndown utility was used to generate hourly offline boundary conditions for the $5 \mathrm{~km}$ nests from the $25 \mathrm{~km}$ runs. The 5 and $1 \mathrm{~km}$ nests were run online without feedback between nests. 
Table 2. Summary of physical parameterisations and other options used in parent and nested simulations.

\begin{tabular}{llll}
\hline Option & $\mathrm{d} 01,25 \mathrm{~km}$ parent & $\mathrm{d} 02,5 \mathrm{~km}$ nest & $\mathrm{d} 03,1 \mathrm{~km}$ nest \\
\hline Horizontal grid cells $\left(n_{i} \times n_{j}\right)$ & $226 \times 196$ & $151 \times 171$ & $141 \times 116$ \\
Horizontal grid spacing & $25 \mathrm{~km}$ & $5 \mathrm{~km}$ & $1 \mathrm{~km}$ \\
Cumulus & Grell 3-D & Grell 3-D & none \\
Subsistence spreading & 1 & 3 & $\mathrm{NA}$ \\
Dynamical time step $(\mathrm{s})$ & 120 & 30 & 6 \\
Chemistry time step $(\mathrm{min})$ & 2 & 1 & 1 \\
Boundary conditions & ECMWF/MACC & offline, ndown & online, no feedback \\
\hline
\end{tabular}

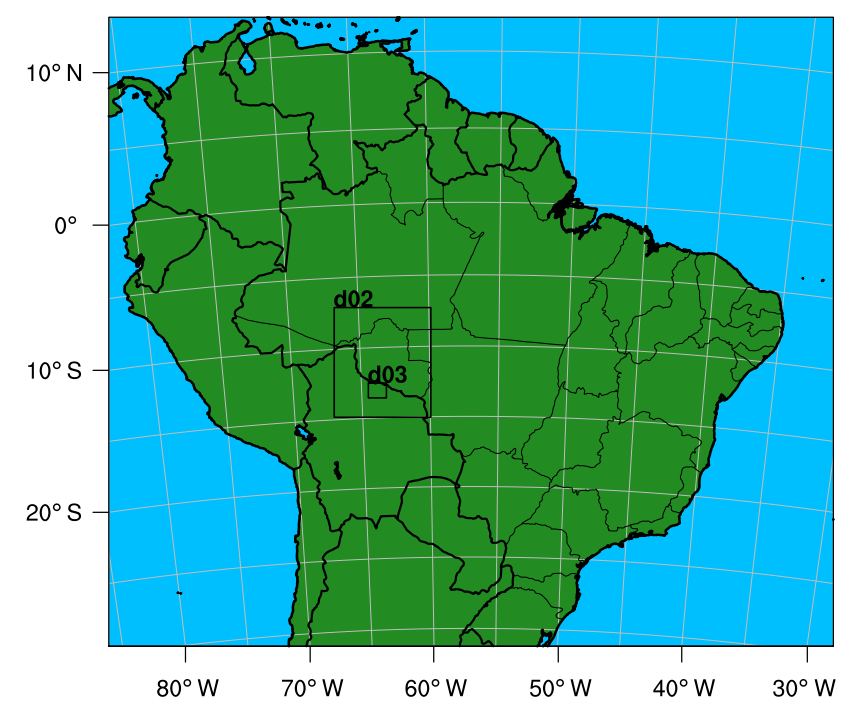

Figure 1. Map of domains used for study. Outer map of parent domain with $25 \mathrm{~km}$ horizontal grid spacing, with squares showing extents of $5 \mathrm{~km}(\mathrm{~d} 02)$ and $1 \mathrm{~km}(\mathrm{~d} 03)$ nests.

Except where otherwise stated, the $5 \mathrm{~km}$ domain uses the Grell-3-D convective scheme with subsidence spreading turned on so as to be applicable for use below $10 \mathrm{~km}$ grid spacing (Grell and Freitas, 2014). No convective parameterisation is used on the $1 \mathrm{~km}$ nest, allowing explicit aerosolcloud interactions in convective clouds. The differences in model setup between domains are summarised in Table 2 . All other physical parameterisations are the same between the nested and parent domains and are described in more detail in Archer-Nicholls et al. (2015).

\subsection{Scenarios}

Two emission scenarios are considered in this study: fire emissions (FE) and no fire emissions (nFE). FE uses the 3BEM fire emissions with the Freitas et al. (2007) plumerise parameterisation and modifications for the 2012 biomass burning season described in Archer-Nicholls et al. (2015). The nFE scenario has no fire emissions but has the same anthropogenic emissions, biogenic emissions and boundary conditions as the FE scenario. Both of these scenarios were
Table 3. Summary of scenarios: fire emissions (FE), no fire emissions (nFE), fire emissions with no aerosol-radiation interactions (nARI) and a control simulation with no fire emissions or aerosolradiation interactions (Ctrl). Scenarios without convective parameterisation on the $5 \mathrm{~km}$ domain (FE_nCU, nFE_nCU, nARI_nCU and Ctrl_nCU) were run only for the 18 September case study.

\begin{tabular}{llll}
\hline Scenario & $\begin{array}{l}\text { Fire } \\
\text { emissions }\end{array}$ & $\begin{array}{l}\text { Aerosol-radiative } \\
\text { feedback }\end{array}$ & $\begin{array}{l}\text { Convective } \\
\text { parameterisation } \\
\text { on 5 km domain }\end{array}$ \\
\hline FE & On & On & On \\
nFE & Off & On & On \\
nARI & On & Off & On \\
Ctrl & Off & Off & On \\
\hline FE_nCU & On & On & Off \\
nFE_nCU & Off & On & Off \\
nARI_nCU & On & Off & Off \\
Ctrl_nCU & Off & Off & Off \\
\hline
\end{tabular}

run for the entirety of September on the $25 \mathrm{~km}$ domain without aerosol-radiation interactions. The meteorological fields were reinitialised from ECMWF fields at the start of each nested simulation run to minimise synoptic-scale error growth and ensure that any differences within the nested domains were due to processes being investigated within the nests.

To separate the impacts of aerosol-radiation interactions from cloud-aerosol interactions, the nested domains were run with aerosol-radiation interactions both turned on and off. References to the FE and nFE scenarios refer to scenarios with aerosol-radiation interactions on. The scenario with no fire emissions or aerosol-radiation interactions is used as a control simulation ( $\mathrm{Ctrl}$ ) and behaves as a WRF simulation would (i.e. with negligible aerosol effects). Another scenario with fire emissions but no aerosol-radiation interactions (nARI) is used to isolate the impacts of cloudaerosol interactions. Finally, each scenario was also run with the Grell-3-D convective parameterisation turned off over the $5 \mathrm{~km}$ domain (denoted with the suffix “_nCU”) for the 18 September 2012 initialisation. The scenarios are summarised in Table 3. 


\subsection{Meteorological and aerosol fields}

Figure 2 shows accumulated precipitation and winds at $700 \mathrm{hPa}$ over the three case study periods over the $5 \mathrm{~km}$ domain. The meteorological input conditions of each nested simulation case study are derived from the ECMWF data, whereas the chemical and aerosol input conditions are interpolated from the $25 \mathrm{~km}$ domain. The first $6 \mathrm{~h}$ of integration of each run are discarded as spin-up.

The modelled meteorological conditions differ markedly for each case study. The driest conditions are on 14 September, with only limited convective precipitation. Prevalent winds are easterly or north-easterly. Extensive fire emissions and minimal precipitation over the region between 10 and 14 September result in high modelled aerosol loadings (Fig. 3). By 18 September the transition into the wet season has begun, with widespread precipitation across the $5 \mathrm{~km}$ domain and the location of the $1 \mathrm{~km}$ nest. Aerosol loadings are lower than on the 14 September but still high. There is heavy precipitation and easterly winds over the northern half of the domain on 23 September but north to north-westerly winds and little precipitation over the southern half (where the $1 \mathrm{~km}$ nest is located). By 23 September, prolonged rainfall has washed out much aerosol. However, the model shows higher aerosol loadings compared to measurements on this date (see Archer-Nicholls et al., 2015, for more details).

The dates of the case studies coincide with the SAMBBA flight numbers B731, B734 and B739. The model output from the parent $25 \mathrm{~km}$ domain was evaluated against these in situ flight measurements by Archer-Nicholls et al. (2015). Modelled POM and $\mathrm{PM}_{2.5}$ mass was of similar magnitude to flight measurements on 14 and 18 September, although sufficient aerosol mass was achieved by scaling up emissions to match observed AOD from the MODIS satellite product in the region. On 23 September, aerosol mass was overestimated in the model compared to flights, which was attributed to a combination of emission fields not decreasing commensurately with the transition into wet-season meteorological conditions and insufficient wet deposition of aerosol mass. Due in part to poorly captured plume rise, the vertical distribution was biased high in the model between the boundary layer top and $4 \mathrm{~km}$ above ground. Although there were some discrepancies in POM : BC ratio between model and observations, single scattering albedo compared reasonably well. Overall, the model reproduced aerosol fields well enough to capture the broad impacts of BBA, acknowledging uncertainties due to an imperfect representation of aerosol vertical distribution and optical properties.

\subsection{Radiative flux calculations}

The public version of WRF-Chem carries 16 diagnostic variables for assessing simulated radiative fluxes. These are first split into SW and LW portions of the spectrum and can be calculated at the TOA or the surface (e.g. $\mathrm{SW}_{\mathrm{TOA}}, \mathrm{SW}_{\mathrm{Sfc}}$ ), in either the up or down direction $\left(\mathrm{SW}_{\mathrm{TOA}}^{\uparrow}, \mathrm{SW}_{\mathrm{TOA}}^{\downarrow}\right)$. Finally, they can be calculated for "all-sky", including the effects of clouds $\left(\mathrm{SW}_{\mathrm{TOA}}^{\uparrow}\right)$; or for "clear sky", ignoring the effects of clouds $\left(\mathrm{SW}_{\mathrm{TOA}, \mathrm{clr}}^{\uparrow}\right)$. Note that the clear-sky variables are not only calculated in the grid points where there is no cloud but for every grid point giving the value that would be returned if no cloud existed.

The change to any of these variables due to the emission of BBA is calculated by finding the difference between the FE scenario and nFE scenario. For example, the change in downward SW radiation at the surface can be found by

$\Delta \mathrm{SW}_{\mathrm{Sfc}}^{\downarrow}=\mathrm{SW}_{\mathrm{Sfc}, \mathrm{FE}}^{\downarrow}-\mathrm{SW}_{\mathrm{Sfc}, \mathrm{nFE}}^{\downarrow}$.

Likewise, the difference in upwelling SW radiation at the TOA is given by

$\Delta \mathrm{SW}_{\mathrm{TOA}}^{\uparrow}=\mathrm{SW}_{\mathrm{TOA}, \mathrm{FE}}^{\uparrow}-\mathrm{SW}_{\mathrm{TOA}, \mathrm{nFE}}^{\uparrow} \cdot$

The radiative balance $(\mathrm{RB})$ is defined as the difference between the radiation going into the system and the outwelling radiation at the TOA:

$\mathrm{RB}=\mathrm{SW}_{\mathrm{TOA}}^{\downarrow}+\mathrm{LW}_{\mathrm{TOA}}^{\downarrow}-\mathrm{SW}_{\mathrm{TOA}}^{\uparrow}-\mathrm{LW}_{\mathrm{TOA}}^{\uparrow}$,

with a positive $R B$ indicating a net increase in energy in the system. As such, the RB is generally positive during the day and negative at night. RB can similarly be calculated for clear-sky conditions:

$$
\begin{aligned}
\mathrm{RB}_{\mathrm{clr}} & =\mathrm{SW}_{\mathrm{TOA}, \mathrm{clr}}^{\downarrow}+\mathrm{LW}_{\mathrm{TOA}, \mathrm{clr}}^{\downarrow}-\mathrm{SW}_{\mathrm{TOA}, \mathrm{clr}}^{\uparrow} \\
& -\mathrm{LW}_{\mathrm{TOA}, \mathrm{clr}}^{\uparrow}
\end{aligned}
$$

The change in radiative balance $(\triangle \mathrm{RB})$ is defined as the difference between a particular scenario and the control simulation (Ctrl) which has no aerosol effects. Given the incoming radiation at the TOA is the same for all scenarios, $\triangle \mathrm{RB}$ is equal to the difference in outgoing radiation, e.g.

$$
\begin{aligned}
\Delta \mathrm{RB}_{\mathrm{FE}} & =\mathrm{RB}_{\mathrm{FE}}-\mathrm{RB}_{\mathrm{Ctrl}}=\left.\left(\mathrm{SW}_{\mathrm{TOA}}^{\uparrow}+\mathrm{LW}_{\mathrm{TOA}}^{\uparrow}\right)\right|_{\mathrm{Ctrl}} \\
& -\left.\left(\mathrm{SW}_{\mathrm{TOA}}^{\uparrow}+\mathrm{LW}_{\mathrm{TOA}}^{\uparrow}\right)\right|_{\mathrm{FE}},
\end{aligned}
$$

making $\triangle \mathrm{RB}_{\mathrm{FE}}$ the instantaneous change to the net radiative flux due to the aerosol population. Similar calculations can be made for the clear-sky variables direct aerosol effects from changes to the cloud fields:

$\Delta \mathrm{RB}_{\mathrm{FE}, \mathrm{clr}}=\mathrm{RB}_{\mathrm{FE}, \mathrm{clr}}-\mathrm{RB}_{\mathrm{Ctrl}, \mathrm{clr}}$.

BBA contains a high proportion of highly absorbing black carbon. The total radiative flux absorbed by the atmosphere can be calculated by finding the difference between fluxes into and out of the atmospheric column:

$$
\mathrm{ASW}=\mathrm{SW}_{\mathrm{TOA}}^{\downarrow}+\mathrm{SW}_{\mathrm{Sfc}}^{\uparrow}-\mathrm{SW}_{\mathrm{TOA}}^{\uparrow}-\mathrm{SW}_{\mathrm{Sfc}}^{\downarrow} .
$$



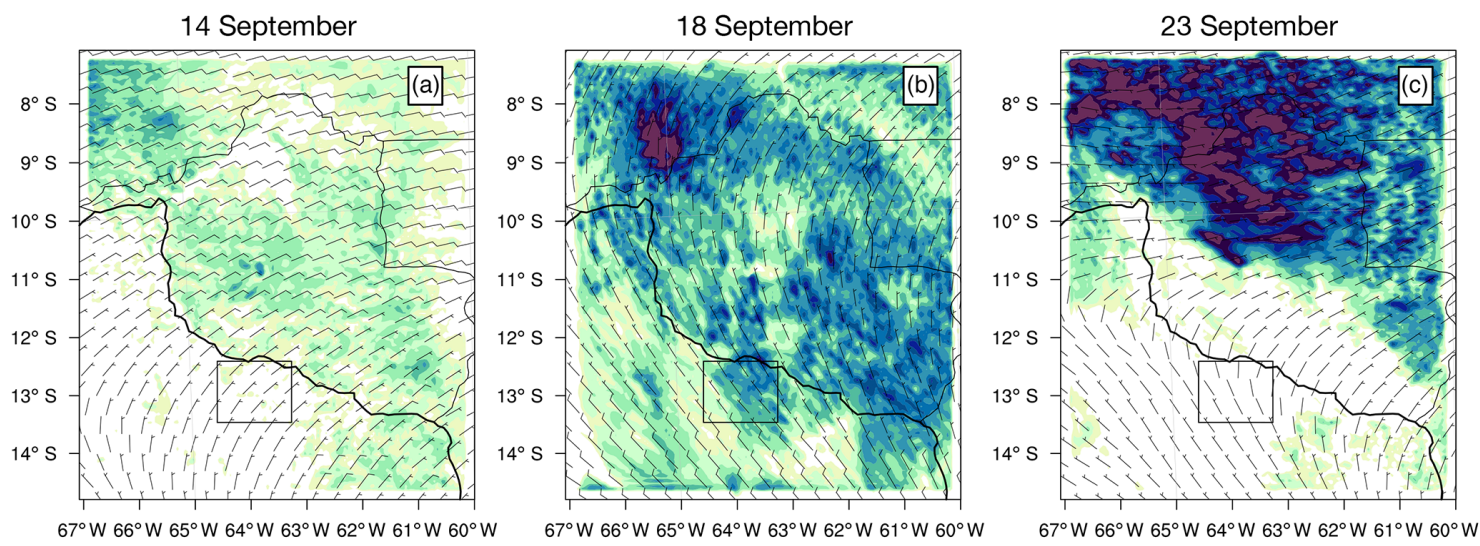

Accumulated Precipitation (mm)

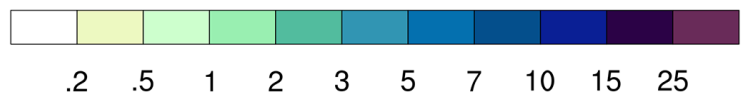

Figure 2. Maps of total precipitation and wind vectors at $700 \mathrm{hPa}$ from the Ctrl scenario, accumulated over $24 \mathrm{~h}$ from dawn to dawn for each case study period over the $5 \mathrm{~km}$ domain, with black box outlining the $1 \mathrm{~km}$ domain. Panel (a): from 10:00 UTC 14 September; panel (b): from 10:00 UTC 18 September 2012; and panel (c): from 10:00 UTC 23 September.
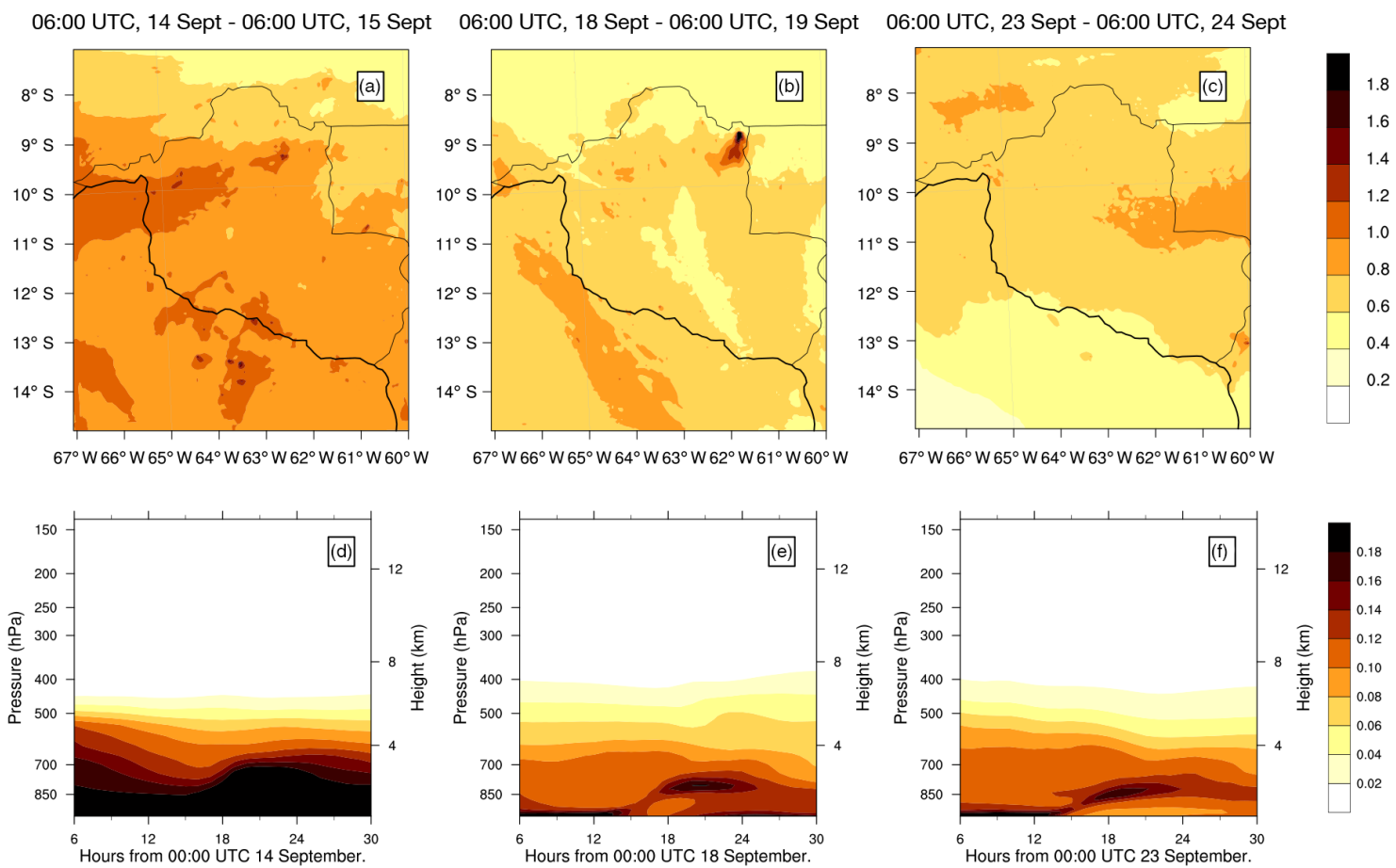

Figure 3. Panels (a-c): temporally averaged column AOD at $550 \mathrm{~nm}$ from $5 \mathrm{~km}$ domain. Panels (d-f): vertical profiles of extinction coefficient $b_{\text {ext }}$ at $550 \mathrm{~nm}\left(\mathrm{~km}^{-1}\right)$, averaged over interpolated pressure level planes at $25 \mathrm{hPa}$ intervals. All data from FE scenario; (a) and (d) from 06:00 UTC 14 September; (b) and (e) from 06:00 UTC 18 September; (c) and (f) from 06:00 UTC 23 September 2012.

The 16 diagnostic radiative flux variables in the public version of WRF-Chem do not, however, provide enough information to fully disentangle the direct, semi-direct and indirect effects. Following Ghan et al. (2012), we have added double calls to the radiation driver in each column to calcu- late an extra set of eight "clean-sky" variables $\left(\mathrm{SW}_{\mathrm{cln}}\right.$ and $L W_{c l n}$ ), which ignore the radiative effects of aerosol by setting the refractive index of all aerosol species to zero. With these extra diagnostics, the influence of aerosol effects on water uptake and absorption can be removed, giving enough 
information to calculate the direct, semi-direct and indirect effects of biomass burning aerosol.

The direct $\mathrm{SW}$ radiative forcing $\left(\mathrm{SW}_{\text {DIRECT }}\right)$ is defined as the difference in upwelling SW radiation at the TOA between the FE and nFE scenarios, with the radiative effects of water vapour removed by subtracting the clean-sky value:

$$
\mathrm{SW}_{\mathrm{DIRECT}}=\Delta \mathrm{SW}_{\mathrm{TOA}}^{\uparrow}-\Delta \mathrm{SW}_{\mathrm{TOA}, \mathrm{cln}}^{\uparrow} .
$$

The indirect effect is calculated from the scenarios with no aerosol radiative interactions:

$$
\begin{aligned}
\mathrm{SW}_{\text {INDIRECT }} & =\Delta \mathrm{SW}_{\mathrm{TOA}, \mathrm{nARI}, \mathrm{cln}}^{\uparrow} \\
& =\mathrm{SW}_{\mathrm{TOA}, \mathrm{nARI}, \mathrm{cln}}^{\uparrow}-\mathrm{SW}_{\mathrm{TOA}, \mathrm{Ctrl}, \mathrm{cln}}^{\uparrow}
\end{aligned}
$$

Finally the semi-direct effect is the remainder after taking away the direct and indirect effects:

$$
\begin{aligned}
\mathrm{SW}_{\text {SEMIDIRECT }} & =\Delta \mathrm{SW}_{\mathrm{TOA}}^{\uparrow}-\mathrm{SW}_{\text {DIRECT }} \\
& -\mathrm{SW}_{\text {INDIRECT }} .
\end{aligned}
$$

Equivalent variables for $\mathrm{LW}$ radiation are also calculated. For more details and discussion, see Ghan et al. (2012).

\subsection{Statistical methods}

For the radiative variables defined above, sample means and standard deviations $(s)$, over the domain (ignoring the five outermost cells of each domain to avoid boundary issues) are calculated. An estimation of the uncertainty is given using the standard error (SE), following a similar method to Kolusu et al. (2015). The SE is typically calculated by dividing the standard deviation by the square root of the number of independent data points $N$. However, the grid points of a model run show strong spatial and temporal autocorrelation. Assuming all grid points are independent results in an erroneously small SE and therefore too high a significance. We therefore apply a correction factor $k$ (Bence, 1995):

$\mathrm{SE}=\frac{s}{\sqrt{N}} k$,

where

$k=\frac{\sqrt{1+\rho}}{\sqrt{1-\rho}}$.

The autocorrelation factor $\rho$ varies from -1 (perfect anticorrelation) to 1 (perfect correlation). Spatial autocorrelation is estimated using the 2-D Moran's-i method for neighbouring points. Thus, if $\rho$ is positive, the correction acts to increase the SE. For the derived variables defined above, the net $\mathrm{SE}$ is estimated by adding the errors for the constituent variables in quadrature. For example, for $\mathrm{SW}_{\text {DIRECT: }}$

$\mathrm{SE}\left(\mathrm{SW}_{\text {DIRECT }}\right)$

$=\sqrt{\begin{array}{l}\mathrm{SE}\left(\mathrm{SW}_{\mathrm{TOA}, \mathrm{FE}}^{\uparrow}\right)^{2}+\mathrm{SE}\left(\mathrm{SW}_{\mathrm{TOA}, \mathrm{nFE}}^{\uparrow}\right)^{2} \\ +\mathrm{SE}\left(\mathrm{SW}_{\mathrm{TOA}, \mathrm{FE}, \mathrm{cln}}^{\uparrow}\right)^{2}+\mathrm{SE}\left(\mathrm{SW}_{\mathrm{TOA}, \mathrm{nFE}, \mathrm{cln}}^{\uparrow}\right)^{2} .\end{array}}$

This method reasonably estimates the uncertainty associated with domain averages, with uncertainty increasing appropriately as the number of grid cells decreases. However, it does not account for the systematic error associated with the boundary conditions of a nested domain, such as the $1 \mathrm{~km}$ domain in this study,

\section{Results}

To assess how the WRF-Chem model simulates the regional impacts of BBA under various model setups and meteorological conditions, the analysis first evaluates the instantaneous direct radiative effects of aerosol-radiation interactions, temporarily ignoring the influence of clouds, in Sect. 4.1. Changes to the atmospheric stability, and how this in turn affects cloud formation and precipitation, are then presented (Sect. 4.2). The radiative balance is evaluated with regard to the cloud response to identify the semi-direct effects, testing the sensitivity of the cloud responses to resolution and convective parameterisation (Sect. 4.3). Finally in Sect. 4.4, aerosol-cloud interactions in the model are investigated. Output from the $5 \mathrm{~km}$ and $1 \mathrm{~km}$ domains and runs with no convective parameterisation over the $5 \mathrm{~km}$ domain are analysed, testing how much of an impact the lack of aerosol-cloud interactions in parameterised clouds has on the simulations.

\subsection{Direct aerosol-radiative interactions and changes to atmospheric stability}

Total column AOD at $550 \mathrm{~nm}$ in the FE model scenario is highest on the 14 September case study, with values between 0.8 and 1.2 over the domain (Fig. 3a). AOD on the other two days is lower, between 0.4 and 1.0 (Fig. 3b-c). The majority of the aerosol layer is in the lower $4 \mathrm{~km}$ of the model's atmosphere. Fresh emissions are injected at altitude during the local afternoon of each day (Fig. 3d-f). Note that the AOD is non-zero in the $\mathrm{nFE}$ scenario, generally between 0.2 and 0.4 , owing to contributions from anthropogenic emissions, dust and other long-range-transported aerosols.

Figure 4 shows maps of the differences in clear-sky (ignoring cloud effects) radiation fluxes between the FE and $\mathrm{nFE}$ scenarios and time series for the four main scenarios averaged over the $5 \mathrm{~km}$ domain for 14 September 2012. Similar figures for 18 and 23 September are included in the Supplement. Downwelling clear-sky SW radiation at the surface $\left(\mathrm{SW}_{\mathrm{Sfc} \text {, clr }}^{\downarrow}\right.$ ) on 14 September 2012 is reduced by 


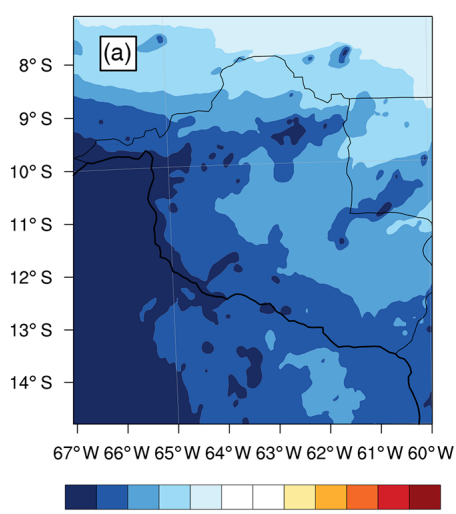

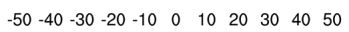
Change in clear-sky surface SW, $5 \mathrm{~km}$ domain

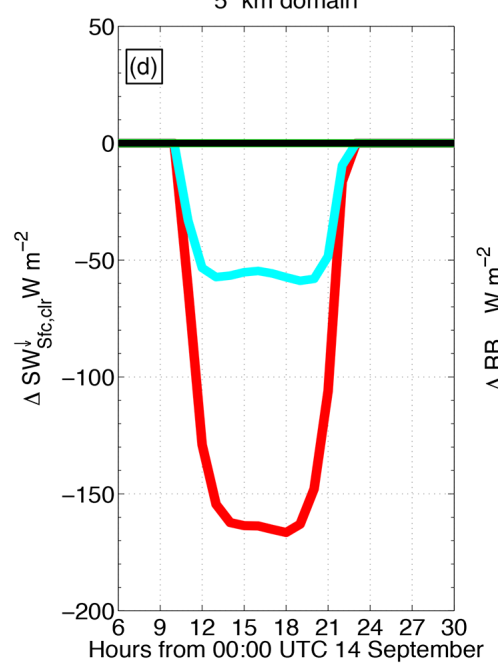

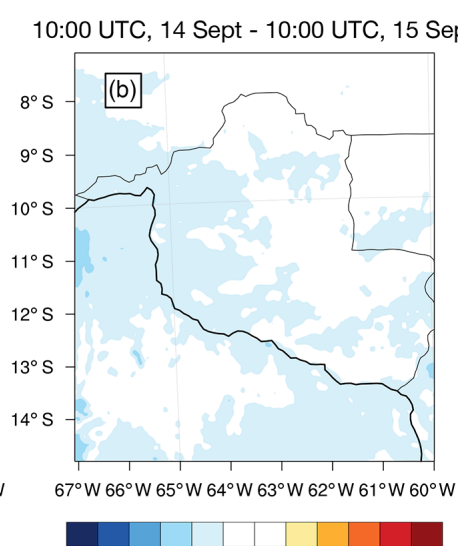

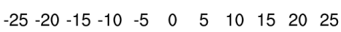

Change in clear-sky radiative balance, $5 \mathrm{~km}$ domain

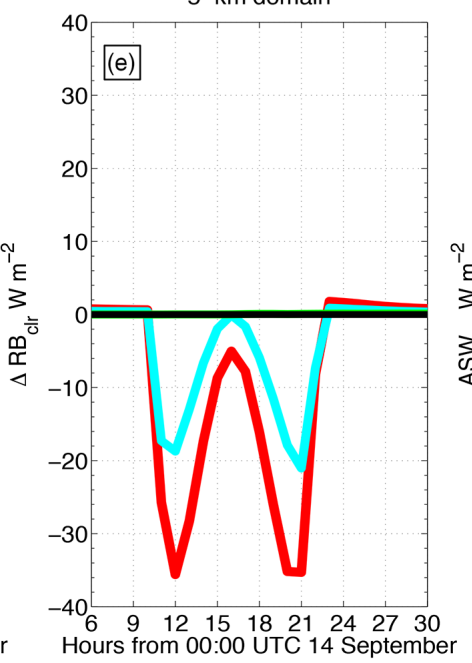

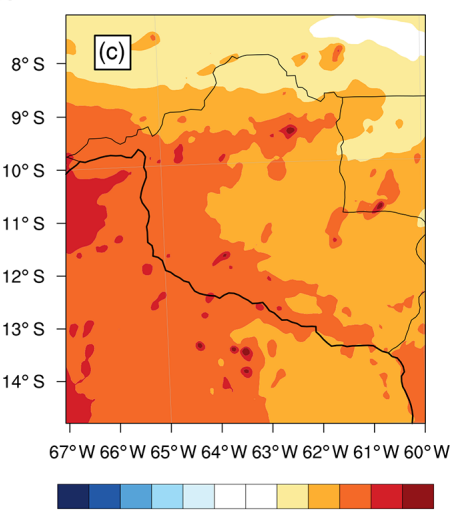

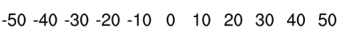

Absorbed clear-sky SW radiation, $5 \mathrm{~km}$ domain

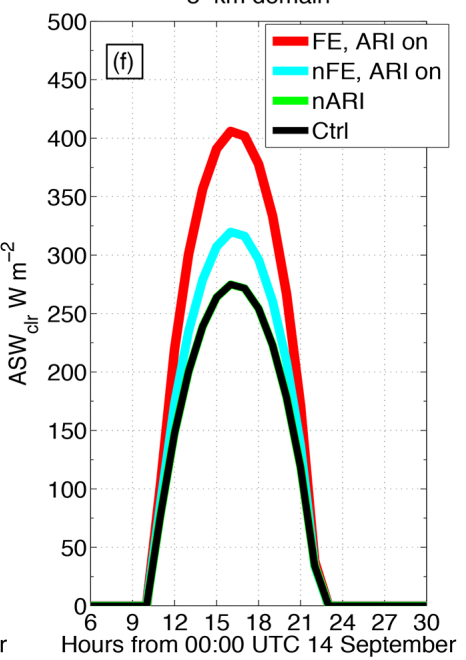

Figure 4. Maps and time series of changes to clear-sky radiation fields (ignoring the effects of clouds) due to BBA over 14 September 2012. Panels (a-c) show maps over the $5 \mathrm{~km}$ domain of the difference between the FE and $\mathrm{nFE}$ scenarios, averaged over $24 \mathrm{~h}$, from dawn to dawn, between 10:00 UTC 14 and 10:00 UTC 15 September. Panels (d-f) show model output averaged over the $5 \mathrm{~km}$ domain at each hour of simulation for the FE, nFE, nARI and Ctrl scenarios, with (d) and (e) plotting the difference from the Ctrl scenario. Panels (a) and (d): change in downwelling SW radiation at the surface $\Delta \mathrm{SW}_{\mathrm{Sfc} \text {, clr }}^{\downarrow}$. Panels (b) and (e): change in radiative balance $\left(\Delta \mathrm{RB}_{\mathrm{clr}}\right)$ at the top of the atmosphere (TOA). Panels (c) and (f): SW radiation absorbed by the atmospheric column $\left(\mathrm{ASW}_{\mathrm{clr}}\right)$.

a maximum of $-109.5 \mathrm{Wm}^{-2}$ compared to the $\mathrm{nFE}$ scenario (Fig. 4a and d). The clear-sky radiative effects in the 18 and 23 September case studies are qualitatively similar to 14 September. The difference in clear-sky radiative balance between the $\mathrm{FE}$ and $\mathrm{nFE}$ scenarios $\left(\Delta \mathrm{RB}_{\mathrm{clr}}\right)$ is negative (i.e. the aerosol layer has a net cooling effect at the TOA if cloud effects are ignored; Fig. $4 \mathrm{~b}$ and e).

Although the high BC content of BBA makes it highly absorbing, it has a net negative forcing because the aerosol layer is predominantly over forest, which has a low albedo of 0.12 in the model. Averaged over $24 \mathrm{~h}$, from dawn to dawn, the difference in $\mathrm{RB}_{\text {clr }}$ between the $\mathrm{FE}$ and $\mathrm{nFE}$ scenarios is $-5.0 \mathrm{~W} \mathrm{~m}^{-2}$.

Over the same period, around $28 \mathrm{~W} \mathrm{~m}^{-2}$ more SW radiation is absorbed by the atmospheric column in the FE sce- nario than the nFE scenario on 14 September (Fig. $4 \mathrm{c}$ and $\mathrm{f}$ ), compared to 19 and $18 \mathrm{~W} \mathrm{~m}^{-2}$ on 18 and 23 September respectively. The full tables of domain-averaged radiative budgets are summarised in the Supplement. These results are comparable in magnitude and sign to a similar study conducted over the same case study area using the Met Office Unified Model (Kolusu et al., 2015). Overall, the net direct radiative effects of the aerosol layer are to reduce the total energy in the system, cool the surface and warm the lower troposphere.

\subsection{Cloud responses to aerosol forcings}

The presence of BBA in the simulations affects the dynamics and stability of the atmosphere, resulting in multiple changes 

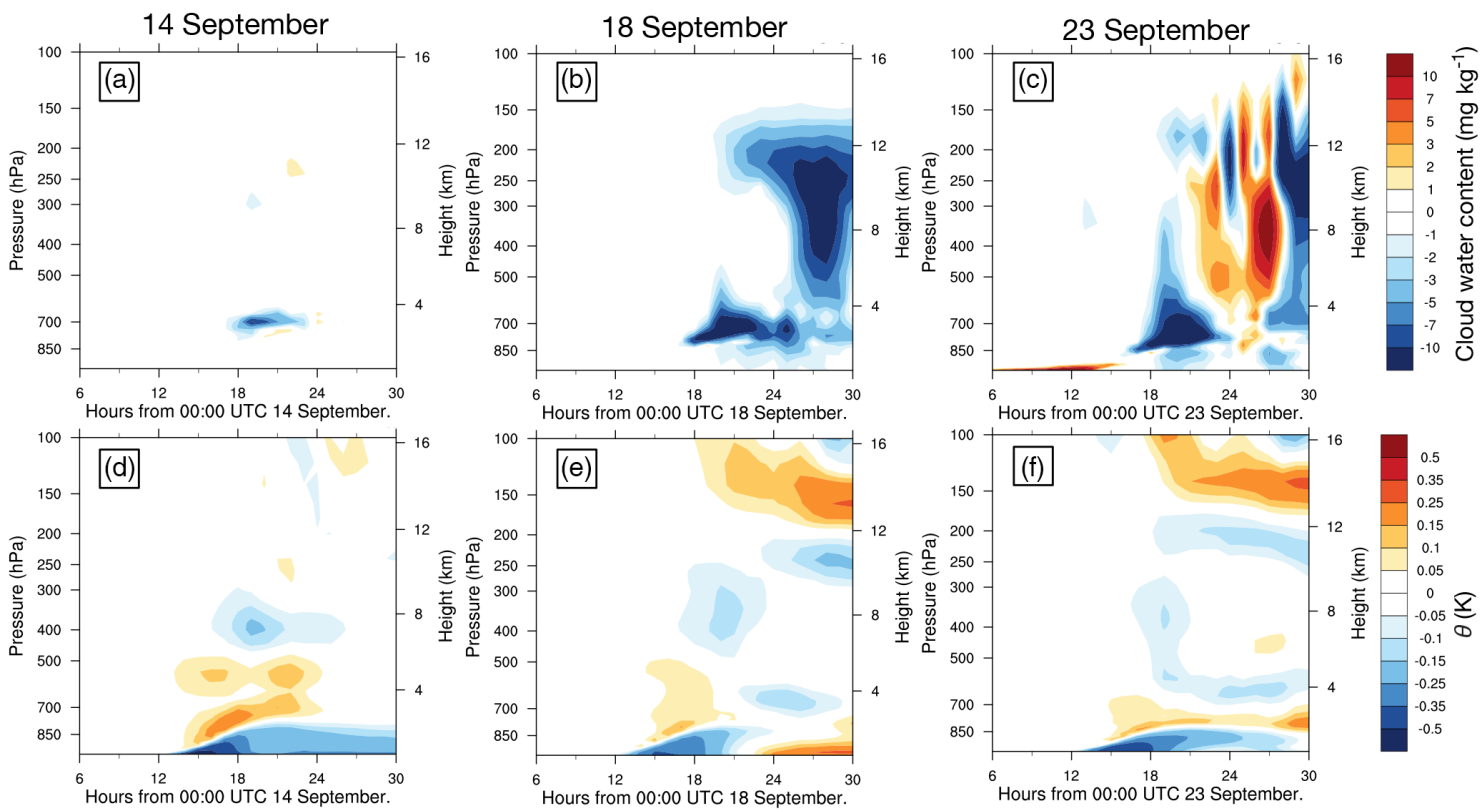

Figure 5. Difference plots between the FE and nFE scenarios with data averaged over interpolated pressure levels with $20 \mathrm{hPa}$ spacing. Panels (a-c): difference in potential temperature $\theta(\mathrm{K})$; panels $(\mathbf{d}-\mathbf{- e})$ : difference in sum of all cloud variables (QCLOUD+QRAIN+QICE+ QGRAUP + QSNOW; $\mathrm{mg} \mathrm{kg}^{-1}$ ). Panels (a) and (d): from 06:00 UTC 14 September; panels (b) and (e): from 06:00 UTC 18 September; panels (c) and (f): from 06:00 UTC 23 September 2012.

to cloud formation and evolution. Changes can be observed in the vertical profile of the domain-averaged potential temperature $\theta$ (Fig. 5a-c). On each day after local sunrise (approximately 10:00 UTC), the surface layer and lower planetary boundary layer (PBL) is cooler in the FE scenario and warmer between 850 and $500 \mathrm{hPa}$. The changes in $\theta$ are indicative of the aerosol layer stabilising the column, inhibiting the initiation of convection and reducing the amount of cloud (Fig. 5d-f). In all three case studies, there is a reduction in cloud formation in the FE scenario during the onset of precipitation around 18:00 to 21:00 UTC (14:00 to 17:00 local time). This change is less dramatic in the 14 September case study, as there was less precipitation on this day compared to the others. On 18 September, the presence of BBA consistently reduces all cloud types into the night. On 23 September, there is some displacement of peak precipitation in the FE scenario, resulting in longer cloud lifetimes and some periods with greater quantities of graupel and snow in the FE scenario. On 18 and 23 September, there is a reduction in nighttime high-altitude ice clouds in the FE scenario.

When the radiative effects of cloud fields are considered for the analysis of model output, the radiative impacts of BBA are dramatically different (Fig. 6). In the mornings, before convective storms occur, $\Delta \mathrm{RB}_{\mathrm{FE}}$ is negative and similar to the clear-sky case in Fig. 4e. In the afternoon, a strong positive forcing is observed in the FE scenario as there is much reduced cloud cover resulting in less SW radiation being reflected to space (see Fig. S3 in Supplement). This difference is greatest on 18 September (the case study with the most precipitation and cloud cover across the domain), peaking at $+70 \mathrm{~W} \mathrm{~m}^{-2}$. This cloud response more than counters the clear-sky direct radiative cooling of the aerosol over the same period.

Similar effects have been found by other modelling studies investigating the impact of BBA over continental regions. For example, Zhang et al. (2008) found a peak negative clearsky forcing of $-8 \mathrm{Wm}^{-2}$ over the highest AOD region in the Amazon but with reductions in cloud cover resulting in localised surface forcings as high as $\approx 22 \mathrm{Wm}^{-2}$ when changes to clouds were included. Kolusu et al. (2015) also show a reduced all-sky forcing magnitude compared to clear sky and a decrease in precipitation due to BBA over the same SAMBBA period using the Met Office Unified Model (MetUM). In Africa, BBA has also been shown to inhibit convection and cloud formation over land (Sakaeda et al., 2011; Tosca et al., 2013).

At nighttime, there is a net negative forcing of approximately $-10 \mathrm{~W} \mathrm{~m}^{-2}$ in the FE run on 18 and 23 September, which occurs because there are fewer ice clouds at high altitude in the FE scenario (Fig. 6). Cirrus clouds efficiently trap LW radiation, and so the thinner ice clouds in the FE simulations result in an increase in $\mathrm{LW}_{\mathrm{TOA}}^{\uparrow}$. Whilst we are unsure of the physical significance of this effect, the forcings due to changes in nighttime ice clouds are comparable in magnitude to the daytime forcings and so have an appreciable impact on the accumulated radiative balance.

The $24 \mathrm{~h}$ averaged radiative budgets for each scenario are summarised in Tables S1-S3 in the Supplement, with av- 

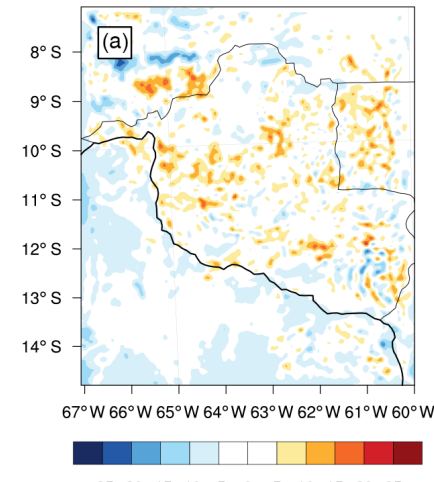

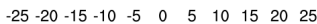
Change in radiative balance, $5 \mathrm{~km}$ domain

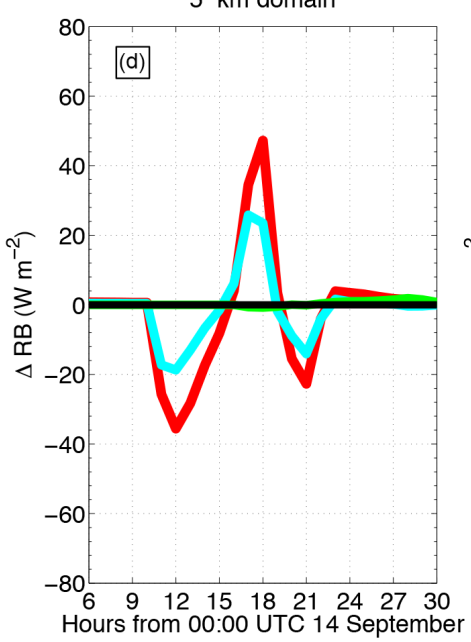

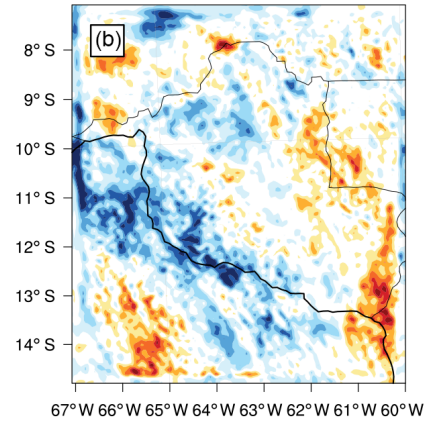

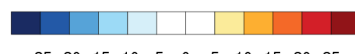

Change in radiative balance, $5 \mathrm{~km}$ domain

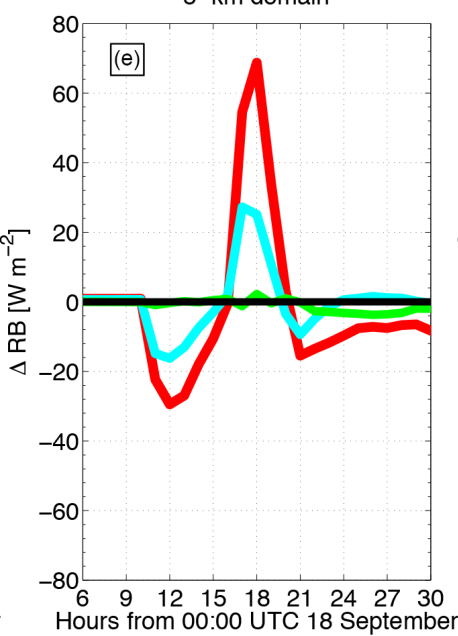

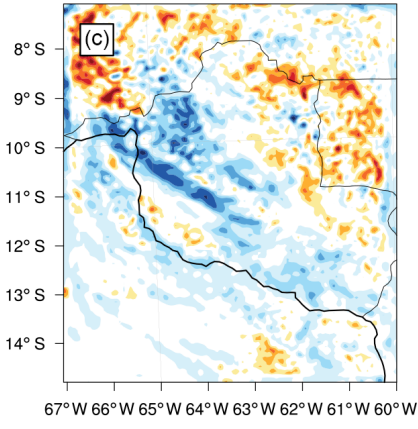

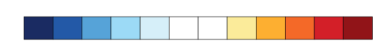

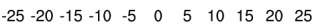
Change in radiative balance, $5 \mathrm{~km}$ domain

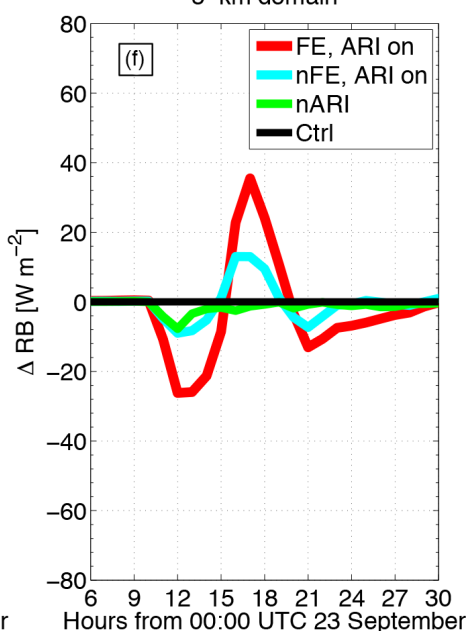

Figure 6. Changes to radiation balance at the TOA over the $5 \mathrm{~km}$ domain for each of the three case study days, including the effects of clouds. Panels $(\mathbf{a}-\mathbf{c})$ show maps over the $5 \mathrm{~km}$ domain of the difference between the FE and $\mathrm{nFE}$ scenarios $\left(\mathrm{RB}_{\mathrm{FE}}-\mathrm{RB}_{\mathrm{nFE}}\right)$, averaged over $24 \mathrm{~h}$, from dawn to dawn, from 10:00 UTC for (a) 14, (b) 18 and (c) 23 September 2012. Panels (d-f): time series of change in radiative balance from $\mathrm{Ctrl}$ scenario $(\triangle \mathrm{RB})$ averaged over the $5 \mathrm{~km}$ domain at each hour of simulation. Calculations of derived variables are explained in Sect. 3.4

erages of basic meteorological variables in Tables S4-S6. Comparing the FE scenario with the $\mathrm{nFE}$ and Ctrl scenarios shows the total aerosol impact. Differences between the nARI and Ctrl scenario are indicative of aerosol-cloud interactions. In each of the case studies, $\mathrm{SW}_{\mathrm{Sfc}}^{\downarrow}$ is lower in the FE scenario, but the net forcing is less consistent. The reduction in cloud cover in the FE scenario adds a semi-direct warming effect which acts counter to the direct cooling of the aerosol, largely cancelling out any net impact.

To quantify this semi-direct effect, we use the methodology of Ghan et al. (2012) to decompose the radiative forcing into SW and LW direct, semi-direct and indirect effects. These are presented for each of the case studies in Fig. 7.

The diurnally averaged $\mathrm{SW}_{\text {DIRECT }}$ is $-5.26 \pm 1.26$, $-3.34 \pm 2.68$ and $-3.65 \pm 1.87 \mathrm{Wm}^{-2}$ respectively on the 14 , 18 and 23 September case studies. When decomposed, the positive change in radiative balance seen in the afternoon in Fig. $6 \mathrm{~d}-\mathrm{f}$ is due to the positive $\mathrm{SW}_{\text {SEMIDIRECT. }}$. Diurnally av- eraged $S W_{\text {SEMIDIRECT }}$ is $3.51 \pm 1.19,6.06 \pm 1.46$ and $5.18 \pm$ 1.82 in the three case studies respectively. At nighttime, the reduction in nighttime cirrus clouds in the FE scenario results in a negative LW $_{\text {SEMIDIRECT }}$ in the 18 and 23 September case studies of $-4.54 \pm 0.96$ and $-2.80 \pm 1.07 \mathrm{Wm}^{-2}$ respectively. In all three case studies, the indirect effects are small relative to the direct and semi-direct forcings, with a signal typically smaller than the estimated error.

Although the broad conclusions using this extended analysis are similar and roughly equivalent to the analysis of the change in radiative balance, the quantification of different forcings enables a greater understanding of the processes and impacts being investigated. However, the results are still specific to the case studies and model setup being studied and should not be extrapolated due to the small scope of the study. 

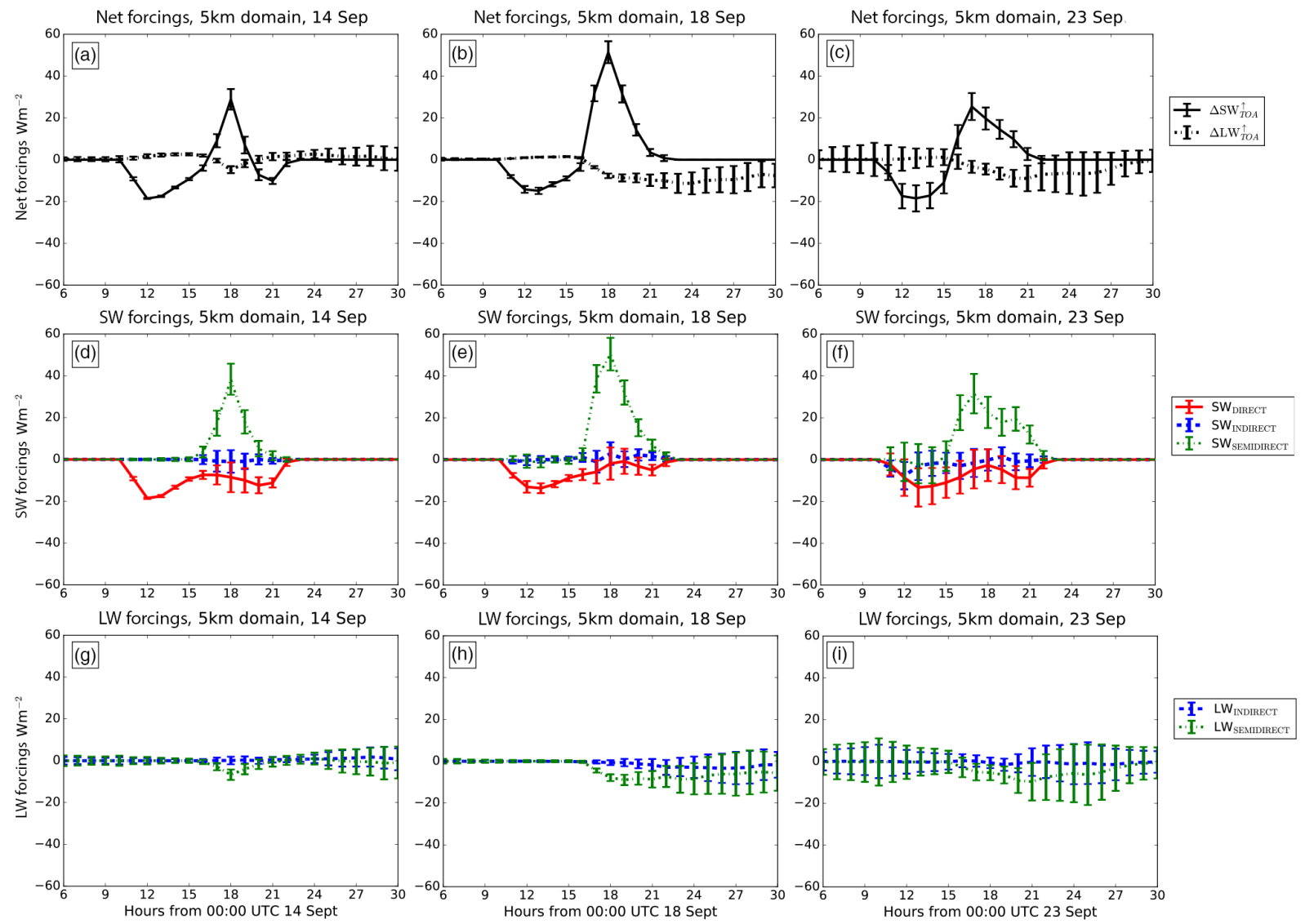

Figure 7. Radiative forcings over $5 \mathrm{~km}$ domain over each case study day: 14 September (left), 18 September (middle) and 23 September (right). Instantaneous net forcings (top) and decomposition into short-wave (middle) and long-wave (bottom) direct, semi-direct and indirect forcings. LW DIRECT is small and so is not plotted.

\subsection{Sensitivity to model resolution and a convective parameterisation}

There are only major differences to the radiative forcings between the 5 and $1 \mathrm{~km}$ domains in the 18 September case study because this is the only day with extensive cloud cover over the $1 \mathrm{~km}$ domain region. In the $1 \mathrm{~km}$ domain, convection initiates faster and more energetically in the early afternoon compared to the same runs on the $5 \mathrm{~km}$ domain. Clouds are better resolved, covering a smaller portion of the total domain. Therefore, a greater amount of SW radiation reaches the ground in the $1 \mathrm{~km}$ domain compared to the same region of the $5 \mathrm{~km}$ domain (Fig. S5a).

The analysis of radiative forcings in the $1 \mathrm{~km}$ domain is limited by its small size. As the region of the $5 \mathrm{~km}$ domain that the $1 \mathrm{~km}$ domain covers is not representative of the whole, displacements of clouds in the $5 \mathrm{~km}$ domain can have a large impact on the net forcing in the $1 \mathrm{~km}$ domain and signals are correspondingly noisier. This is highlighted by the large errors of variables calculated over the $1 \mathrm{~km}$ domain region from the $5 \mathrm{~km}$ domain (Fig. 8). However, sensitivities to the model resolution can be inferred from how forcings dif- fer over the same area between the 1 and $5 \mathrm{~km}$ simulations. $\mathrm{SW}_{\text {SEMIDIRECT }}$ is weaker in the $1 \mathrm{~km}$ domain compared to the same region of the $5 \mathrm{~km}$ domain (Fig. 8a, c and e), due to the smaller, more cellular structure of convective clouds in the $1 \mathrm{~km}$ domain. Assuming the representation of convective clouds is more realistic in the $1 \mathrm{~km}$ domain, the difference between the two domains suggests that the Grell-3-D parameterisation, even with subsidence spreading, may resolve clouds and their radiative properties too poorly for the accurate simulation of semi-direct effects.

To separate changes due to the aerosol fields from effects due to the convective parameterisation, a set of four scenarios without the Grell-3-D convective parameterisation over the $5 \mathrm{~km}$ domain were run for the 18 September case study. Peak precipitation rates (which occur between 20:00 and 21:00 UTC on 18 September) for the FE and FE_nCU scenarios are compared with data from the Tropical Rainfall Measurement Missions (TRMM) 3B42 product (Huffman et al., 2001) in Fig. 9. In the FE scenario, precipitation is less intense and covers a larger area, whereas in the $1 \mathrm{~km}$ domain and FE_nCU scenario, precipitation organises itself into isolated convective cells with a greater portion of 

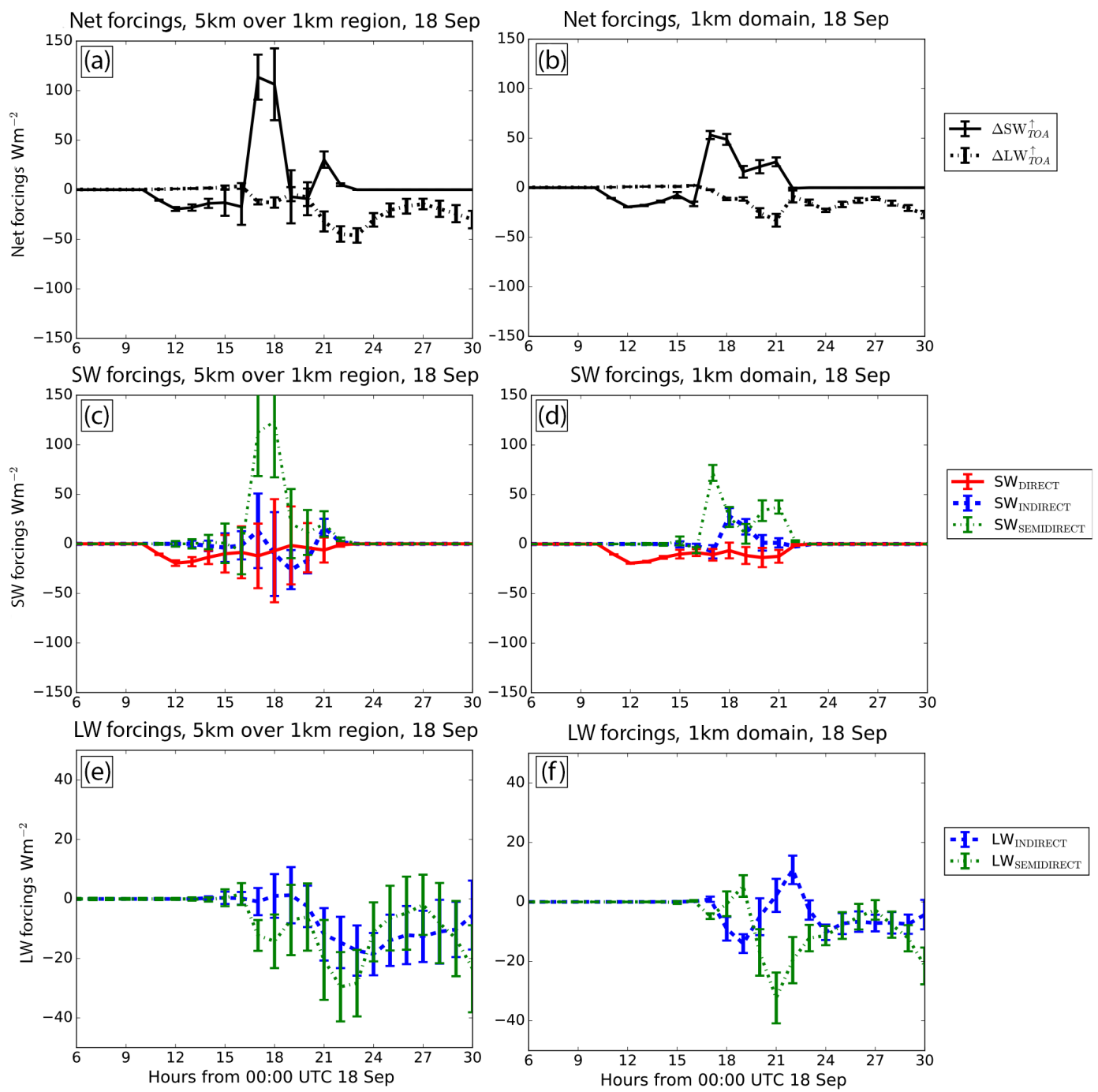

Figure 8. Radiative forcings averaged over the $1 \mathrm{~km}$ region of the $5 \mathrm{~km}$ domain (left) and the $1 \mathrm{~km}$ domain (right) on $18 \mathrm{September}$. Instantaneous net forcings (top), with decomposition into short-wave (middle) and long-wave (bottom) direct, semi-direct and indirect forcings.

the domain receiving no precipitation. The FE scenario correspondingly has a larger portion of the domain covered by cloud at any one time. However, total precipitation over both domains is greater in the FE scenario than the FE_nCU scenario. Although the TRMM product is relatively coarse (with a grid spacing of $0.25^{\circ}$ ), precipitation can be seen to occur in small convective cells, suggesting that the FE_nCU scenario is more realistic.

The spread of accumulated precipitation in the FE_nCU scenario is closer to that of the TRMM data set than the FE scenario (Fig. 10), with more grid cells receiving little to no precipitation and a greater proportion of total precipitation being received from grid cells with high precipitation. The average accumulated precipitation over the $5 \mathrm{~km}$ domain on 18 September is $2.30,1.43$ and $1.49 \mathrm{~mm}$ for the FE, FE_nCU and TRMM data set respectively. Thus, the model scenarios without convective parameterisation perform better for both total accumulated precipitation and distribution over the domain for this case study.

The runs without convective parameterisation have reduced deep convection in the local afternoon, resulting in more downwelling SW radiation at the surface (Fig. S6a). The change in surface SW radiation in the local afternoon is approximately twice as sensitive to the use of convective parameterisation as to the presence of BBA. Overall, the afternoon peak semi-direct effect is weaker when running without convective parameterisation in both the 5 and $1 \mathrm{~km}$ domain (Fig. 11). The diurnally averaged value is $3.61 \pm 8.55$, compared with $6.06 \pm 1.46 \mathrm{Wm}^{-2}$ over the same period from the runs with convective parameterisation. There is also no negative nighttime LW semi-direct forcing, due to the lack of high-altitude nighttime clouds in the runs without convective parameterisation. Even with aerosol-cloud interactions being present in simulations without convective parameterisa- 


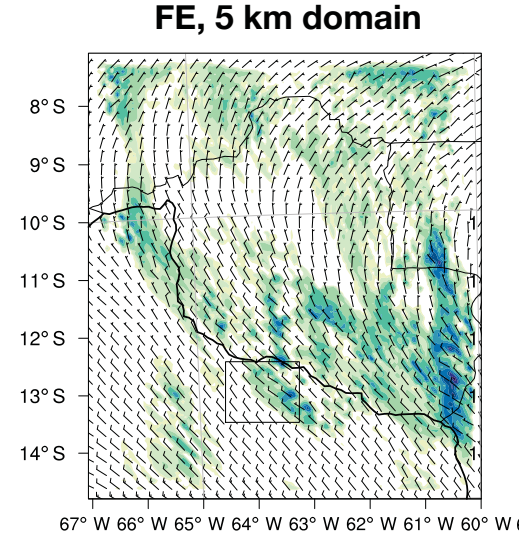

FE, $1 \mathrm{~km}$ domain

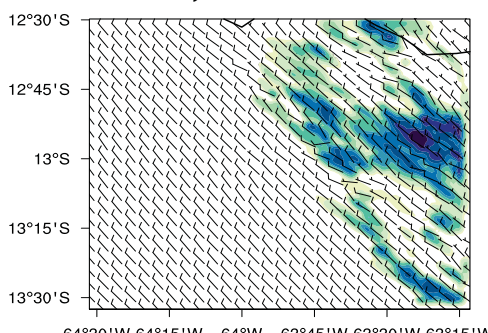

$64^{\circ} 30^{\prime} \mathrm{W} 64^{\circ} 15^{\prime} \mathrm{W} \quad 64^{\circ} \mathrm{W} \quad 63^{\circ} 45^{\prime} \mathrm{W} 63^{\circ} 30^{\prime} \mathrm{W} 63^{\circ} 15^{\prime} \mathrm{W} 64^{\circ} 30^{\prime} \mathrm{W} 64^{\circ} 15^{\prime} \mathrm{W} \quad 64^{\circ} \mathrm{W} \quad 63^{\circ} 45^{\prime} \mathrm{W} 63^{\circ} 30^{\prime} \mathrm{W} 63^{\circ} 15^{\prime} \mathrm{W}$
FE_nCU, 5 km domain

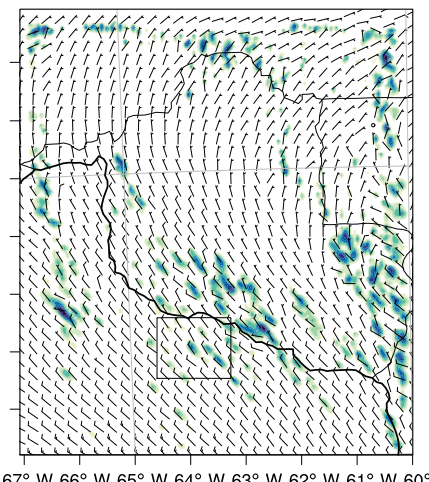

FE_nCU, 1 km domain

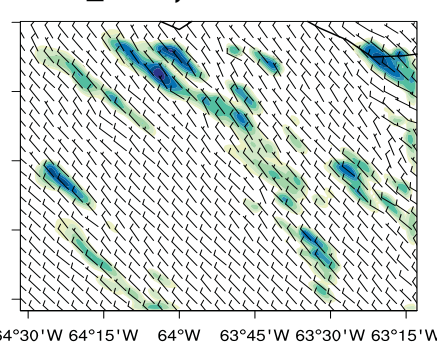

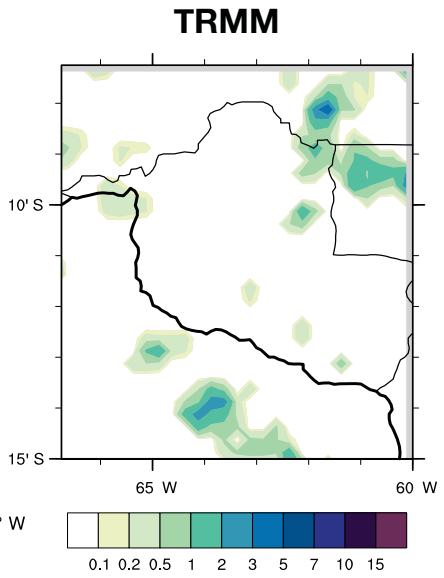

Precipitation rate $\left(\mathrm{mm} \mathrm{h}^{-1}\right)$

Figure 9. Peak precipitation rate over $5 \mathrm{~km}$ and $1 \mathrm{~km}$ domains from FE and FE_nCU scenarios between 20:00 and 21:00 UTC on 18 September 2012, compared with the precipitation rate over the same region from TRMM data at 21:00 UTC on 18 September.

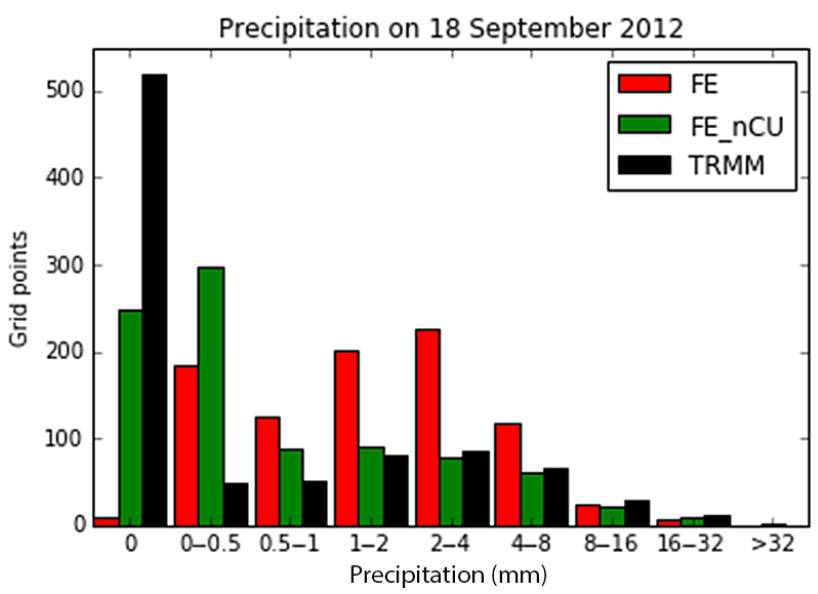

Figure 10. Histogram of $24 \mathrm{~h}$ accumulated precipitation over the $5 \mathrm{~km}$ domain between 10:00 UTC 18 September and 10:00 UTC 19 September 2012, comparing FE and FE_nCU scenarios with TRMM data. Model output averaged over $5 \times 5 \operatorname{grid}(25 \mathrm{~km})$ to be of the equivalent resolution to TRMM data $\left(0.25 \times 0.25^{\circ}\right)$.

tion in the $5 \mathrm{~km}$ domain, the indirect effects are small with no signal above noise. The strong sensitivity of the semi-direct effect to the use of convective parameterisation, combined with low indirect forcings in this region, highlights the need to better develop parameterisations that can accurately simulate aerosol feedbacks on cloud formation.

\subsection{Evidence of aerosol-cloud interactions}

To show that BBA are activating to become cloud droplets in the model, we estimate the maximum supersaturation $S_{\max }$ in each column of the model with cloud by comparing the maximum droplet number in a vertical column $\left(N_{\mathrm{d}, \max }\right)$ with the CCN concentrations at the base of the cloud. For example, if $N_{\mathrm{d}, \max }>\mathrm{CCN}_{0.02}$ but $N_{\mathrm{d}, \max }<\mathrm{CCN}_{0.1}$, then $S_{\text {max }}$ must be between 0.02 and $0.1 \%$. This approach implicitly assumes that peak $S_{\max }$ is at cloud base, which is a reasonable assumption given the representation by the AbdulRazzak and Ghan (2002) activation parameterisation, but it might not be the case in a parcel model or reality.

Figures 12 and 13 show an increase in $N_{\mathrm{d} \text {, max }}$ and a corresponding decrease in $S_{\max }$ in the FE scenario, consistent with increased CCN activation. Because the Abdul-Razzak and Ghan (2002) parameterisation estimates the activated fraction based on a Gaussian distribution of the updraft velocity $(w), N_{\mathrm{d}, \max }$ and $S_{\max }$ are both implicitly sensitive to $w$. However, most clouds over this period and region were convective and parameterised on the $5 \mathrm{~km}$ domain, meaning the subgrid variation in vertical velocities is unresolved. To identify any aerosol-cloud interactions in convective systems, simulations on cloud-resolving scales must be run. Comparing 

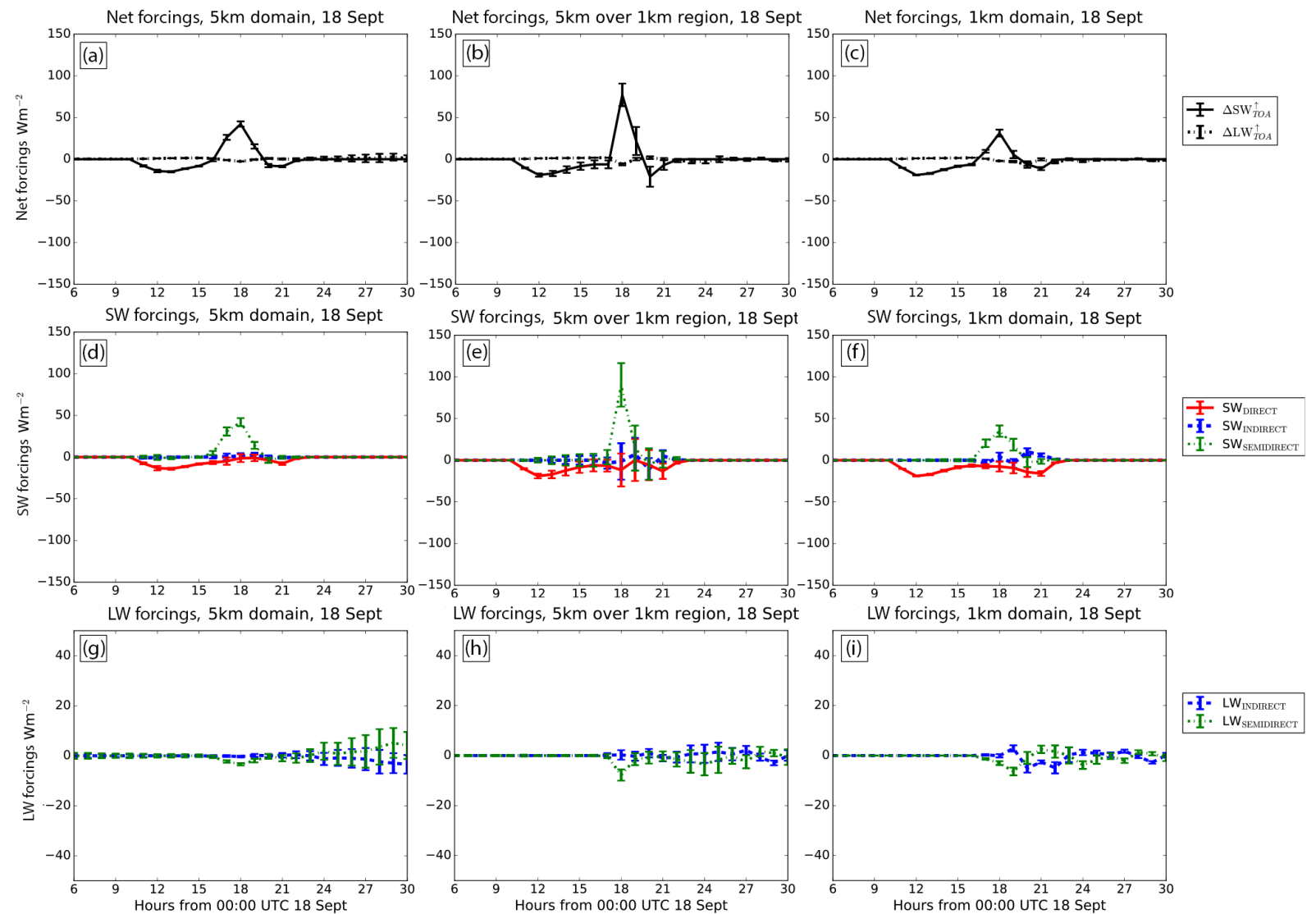

Figure 11. Radiative forcings from scenarios with no convective parameterisation on the $5 \mathrm{~km}$ domain for the 18 September case study. Instantaneous net forcings (top), with decomposition into short-wave (middle) and long-wave (bottom) direct, semi-direct and indirect forcings. Averaged over the $5 \mathrm{~km}$ domain (left), the $1 \mathrm{~km}$ region of the $5 \mathrm{~km}$ domain (middle) and the $1 \mathrm{~km}$ domain (right).

clouds in the same region of the 5 and $1 \mathrm{~km}$ domain, $S_{\max }$ and $N_{\mathrm{d} \text {, max }}$ are both approximately twice as high in the $1 \mathrm{~km}$ simulations in both $\mathrm{FE}$ and $\mathrm{nFE}$ scenarios, implying higher resolved updraft velocities (Fig. 13). More CCN per unit volume are activated in the $1 \mathrm{~km}$ domain due to $w$ being explicitly resolved. However, there is no corresponding increase in scattered radiation, as may be expected from the first indirect effect, because deep convective clouds are already optically thick. Cloud optical depth is most sensitive to an increase in droplet number if the liquid water path is low (Twomey, 1974).

Although CCN are activated in cloud within the model, the net radiative balance was largely not sensitive to aerosolcloud interactions during the case studies, resulting in small indirect effects (Figs. 7 to 11). We believe the small indirect effect is because most of the cloud in the domain is a result of deep convection, which tends to be optically thick even without the inclusion of additional aerosol as described by the Twomey (1974) effect. An exception is on the morning of 23 September 2012 between 11:00 and 14:00 UTC, when there is a small negative $\mathrm{SW}_{\text {INDIRECT }}$ forcing (Fig. 7f). The large central region in Fig. 12a shows a high droplet number in the FE scenario, whereas there is little cloud over the same region of the nFE run (Fig. 12c). This cloud is a groundlevel radiation fog, which forms in the high morning humidity of the forest and is enhanced by the added presence of CCN from BBA. This example is the only period of the case studies where BBA aerosol influences the optical properties of resolved clouds in the $5 \mathrm{~km}$ domain, producing a $\mathrm{SW}_{\text {INDIRECT }}$ forcing of greater magnitude than the simultaneous $\mathrm{SW}_{\text {SEMIDIRECT }}$ forcing.

\section{Conclusions}

WRF-Chem model simulations for three $36 \mathrm{~h}$ case studies over nested domains at a 5 and $1 \mathrm{~km}$ horizontal grid spacing were conducted over a region of Brazil heavily influenced by biomass burning aerosol (BBA) to evaluate the regional impact of aerosol-radiation and aerosol-cloud interactions. These nested domains were driven by model fields from a WRF-Chem simulation at a $25 \mathrm{~km}$ grid spacing over South America, which was run for September 2012 and evaluated by Archer-Nicholls et al. (2015) against in situ aircraft measurements. The Grell-3-D convective parameterisation was 
FE 5 km domain

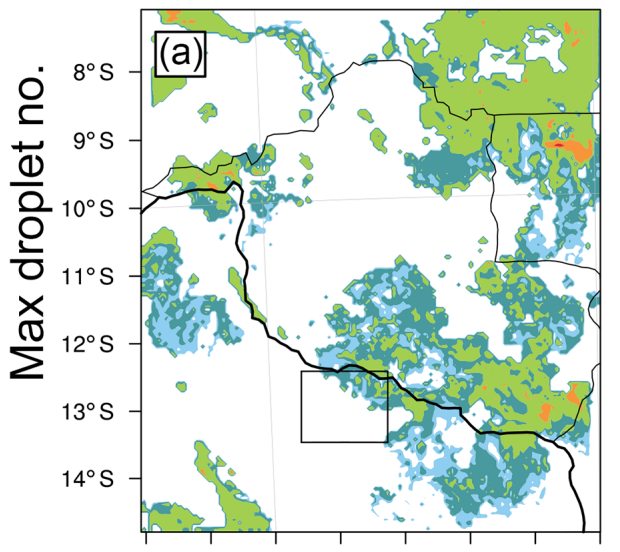

$67^{\circ} \mathrm{W} 66^{\circ} \mathrm{W} 65^{\circ} \mathrm{W} 64^{\circ} \mathrm{W} 63^{\circ} \mathrm{W} 62^{\circ} \mathrm{W} 61^{\circ} \mathrm{W} 60^{\circ} \mathrm{W}$

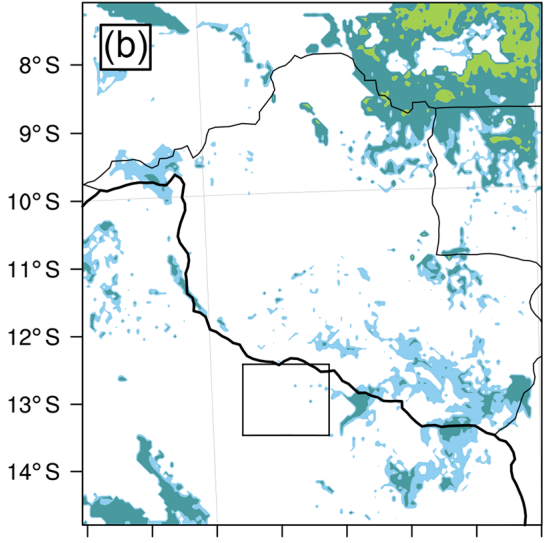

$67^{\circ} \mathrm{W} 66^{\circ} \mathrm{W} 65^{\circ} \mathrm{W} 64^{\circ} \mathrm{W} 63^{\circ} \mathrm{W} 62^{\circ} \mathrm{W} 61^{\circ} \mathrm{W} 60^{\circ} \mathrm{W}$

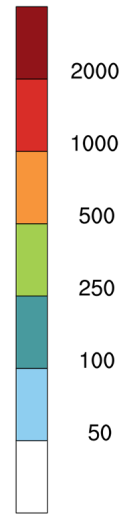

1000

500

250

100

50

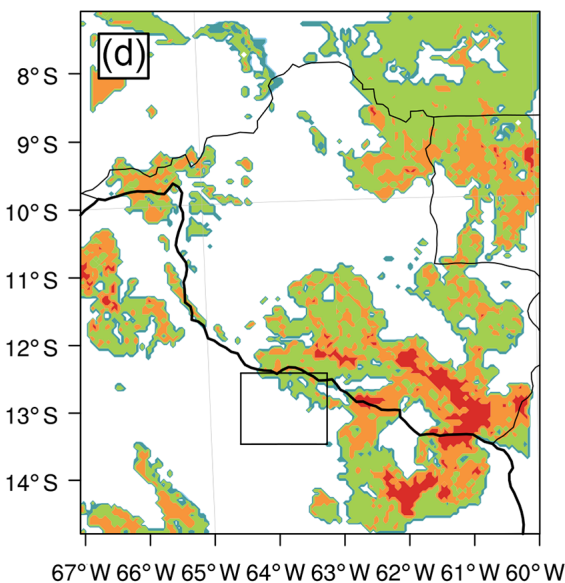

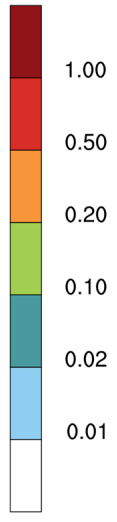

0.01 $67^{\circ} \mathrm{W} 66^{\circ} \mathrm{W} 65^{\circ} \mathrm{W} 64^{\circ} \mathrm{W} 63^{\circ} \mathrm{W} 62^{\circ} \mathrm{W} 61^{\circ} \mathrm{W} 60^{\circ} \mathrm{W}$

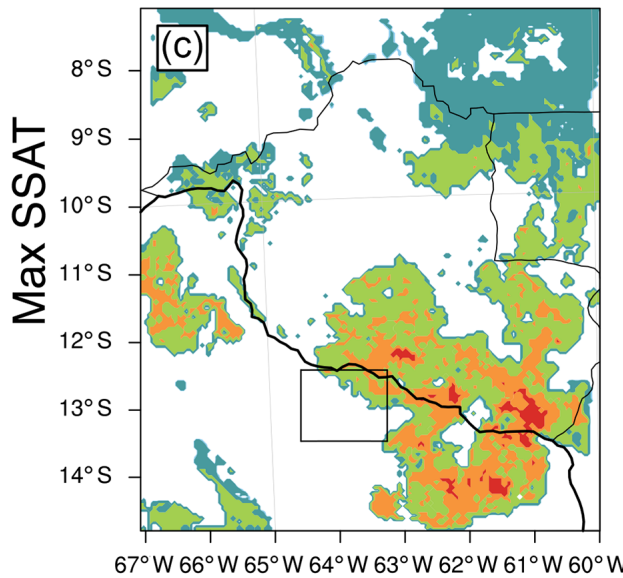

Figure 12. Comparison of maximum droplet number in column $N_{\mathrm{d}, \max }\left(\mathrm{cm}^{-3}\right)$ and estimated maximum cloud supersaturation $S_{\mathrm{max}}(\%)$ between the FE and nFE scenarios over the $5 \mathrm{~km}$ domain on 10:00 UTC (approximately 06:00 LT) 23 September 2012. Panels (a) and (c): plots of $N_{\mathrm{d} \text {, max }}$; panels (b) and (d): plots of $S_{\max }$. Panels (a) and (b) for FE scenario; panels (c) and (d) for nFE scenario.

used on the $5 \mathrm{~km}$ domain, using the recommended subsistence spreading option for running on this scale (Grell and Freitas, 2014). Different scenarios were conducted to probe how effectively the impacts are modelled in WRF-Chem and test sensitivity to model resolution and use of convective parameterisation over the $5 \mathrm{~km}$ domain. As a result of the small size of domains, short case studies and a single model version, the results from this study apply to the specific case studies and model setup presented. Caution should be used when extrapolating from the results of these case studies to draw more general conclusions about aerosol-cloud interactions (especially if applying these findings to other limited areas or to global climate models).

Over the $5 \mathrm{~km}$ domain, in the 18 September case study, the short-wave direct effects of BBA particles over the region have a negative forcing of $-3.34 \pm 1.47 \mathrm{Wm}^{-2}$, which is countered by a positive semi-direct effect of $6.06 \pm$ $1.46 \mathrm{Wm}^{-2}$. The short-wave indirect effect is a relatively small $0.266 \pm 1.06 \mathrm{Wm}^{-2}$. Long-wave semi-direct and indirect effects are larger on this case study day, with values of $-4.54 \pm 0.96 \mathrm{Wm}^{-2}$ and $-1.53 \pm 0.69 \mathrm{Wm}^{-2}$ respectively. These are largely a result of decreases in nighttime cirrus clouds in the runs with BBA. Overall, there is a net negative forcing of $-2.67 \pm 1.27 \mathrm{Wm}^{-2}$.

Further nested simulations at a $1 \mathrm{~km}$ grid spacing were run to explicitly resolve convection. In the finer-resolution domain, deep convective clouds have much reduced horizontal spread but a higher cloud droplet number within cloud compared to the $5 \mathrm{~km}$ domain. The reduction in cloud cover due to the presence of BBA over the $1 \mathrm{~km}$ domain therefore has a reduced impact on the net radiative balance, and the magnitude of the semi-direct effect is smaller compared to the same region of the $5 \mathrm{~km}$ domain. The modelled semi-direct effect is thus highly sensitive to the model resolution. Indirect effects from resolved aerosol-cloud interactions in the $1 \mathrm{~km}$ domain were smaller than the semi-direct effect, although the 

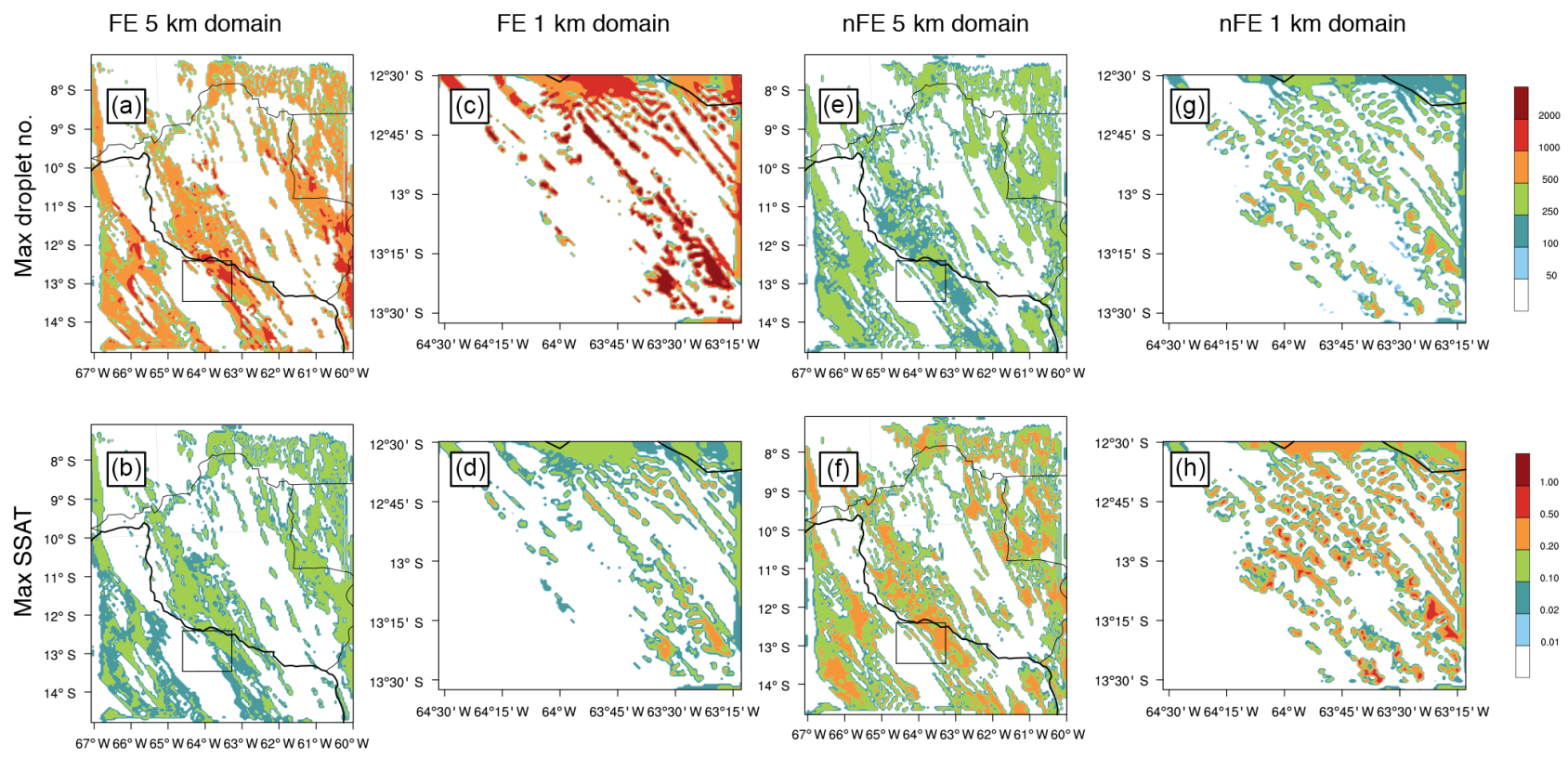

Figure 13. Comparison of maximum droplet number $N_{\mathrm{d}, \max }\left(\mathrm{cm}^{-3}\right)$ and maximum cloud supersaturation $S_{\max }(\%)$ between the FE and nFE scenarios over the 5 and $1 \mathrm{~km}$ domains at 18:00 UTC (approximately 14:00 LT) 18 September 2012. Panels (a), (c), (e) and (g): plots of $N_{\mathrm{d}, \max }$; panels (b), (d), (f) and (h): plots of $S_{\max }$. Panels (a-d): for FE scenario; panels (e-h): for nFE scenario.

small size of the $1 \mathrm{~km}$ domain and the sensitivity to boundary conditions from the $5 \mathrm{~km}$ domain results in a noisy signal.

Simulations run without a convective parameterisation on the $5 \mathrm{~km}$ domain had reduced daytime convection and precipitation. Comparisons with the TRMM data set suggest that the $5 \mathrm{~km}$ simulations without convective parameterisation organise the structure of convective systems better as isolated cells rather than widespread precipitation. The positive semidirect effect is lower in the scenarios without convective parameterisation due to the clouds being more cellular, but the negative nighttime long-wave semi-direct effect is also diminished. The net forcing from the scenarios with no convective parameterisation in the 18 September case study is $1.04 \pm 0.78 \mathrm{Wm}^{-2}$. The large sensitivity to the use of convective parameterisation highlights the uncertainties with simulating aerosol-radiation-cloud interactions in this regime.

The BBA CCN are efficiently activated in the model, as shown by an increase in droplet number and a decrease in maximum supersaturation in clouds. With the exception of an enhanced fog formation event on the morning of 23 September, aerosol-cloud interactions did not cause a noticeable change to the radiative balance. More $\mathrm{CCN}$ are activated in deep convective clouds in runs with fire emissions and convective parameterisation, but without resolving the high in-cloud updraft velocities, the physical significance of the modelled droplet number and grid-scale cloud properties of parameterised cloud is questionable. The runs with explicitly resolved convection at $1 \mathrm{~km}$ and no cumulus parameterisation at $5 \mathrm{~km}$ also show minimal indirect effects, likely due to the deep convective clouds being optically thick and therefore not sensitive to increased droplet number. The model does not produce an aerosol "cloud-invigoration" effect, as seen by Rosenfeld et al. (2008) and Fan et al. (2013), although this may be because aerosol-ice nucleation processes are required to reproduce this effect. Overall, these findings suggest that resolving indirect processes in parameterised cloud is of secondary importance for the current case studies. Instead, the representation of semi-direct aerosol feedbacks has a greater impact on the net radiative balance and associated uncertainties.

Simulating convective systems with the effects of aerosol included, particularly at horizontal grid spacings of less than $10 \mathrm{~km}$, is a challenging task and work is being conducted to develop new parameterisations for this purpose (e.g. Grell and Freitas, 2014; Berg et al., 2015). The semi-direct effects are impossible to quantify reliably in this WRF-Chem setup due to this high sensitivity to the use of convective parameterisation and model resolution. More coordination between parameterised and explicit treatments of aerosol, cloud and radiation interactions is needed in order to make modelling of these processes at the transition between fully parameterised and fully explicit schemes more consistent. To constrain the simulation of these interactions, in situ observations of aerosol size distribution and composition properties, measured before, during and after cloud processing, need to be considered alongside remote sensing observations of changes to cloud cover and net radiation in regions of high aerosol loading. Without a consistent methodology for sim- 
ulating aerosol-radiation-cloud interactions across scales, it is impossible to be sure how much of an impact the aerosol should be having on cloud properties and lifetime.

\section{The Supplement related to this article is available online at doi:10.5194/acp-16-5573-2016-supplement.}

Acknowledgements. This work was funded by the Natural Environment Research Council (NERC) as part of the SAMBBA project under grant NE/J010073/1. S. ArcherNicholls was supported by a NERC quota studentship, with partial support from NERC grant NE/J009202/1. Model simulations were carried out on the ARCHER UK National Supercomputing Service (http://www.archer.ac.uk). Version 3.4.1 of the WRF-Chem model is available from http://www2.mmm.ucar.edu/wrf/users/download/get_source.html. The code modifications following Archer-Nicholls et al. (2015) used in the current study can be obtained by contacting the corresponding author. We thank B. Johnson, S. Kolusu and J. Marsham for helpful discussions on the paper. Analysis and figures were generated using NCAR Command Language v6.1.2 (http://www.ncl.ucar.edu/). We thank the developers of example scripts and WRF-specific functions, which we have used and modified extensively to carry out the presented analysis. We thank the two anonymous reviews for their insightful and helpful comments.

Edited by: G. Myhre

\section{References}

Abdul-Razzak, H. and Ghan, S. J.: A parameterization of aerosol activation 2. multiple aerosol types, J. Geophys. Res., 105, 68376844, 2000.

Abdul-Razzak, H. and Ghan, S. J.: A parameterization of aerosol activation 3. sectional representation, J. Geophys. Res., 107, D3, doi:10.1029/2001JD000483, 2002.

Ackerman, A. S., Toon, O. B., Stevens, D. E., Heymsfield, A. J., Ramanathan, V., and Welton, E. J.: Reduction of tropical cloudiness by soot, Science, 288, 1042-1047, doi:10.1126/science.288.5468.1042, 2000.

Allen, R. J. and Sherwood, S. C.: Aerosol-cloud semi-direct effect and land-sea temperature contrast in a GCM, Geophys. Res. Lett., 37, L07702, doi:10.1029/2010GL042759, 2010.

Andreae, M. O. and Rosenfeld, D.: Aerosol-cloudprecipitation interactions, Part 1 . The nature and sources of cloud-active aerosols, Earth-Sci. Rev., 89, 13-41, doi:10.1016/j.earscirev.2008.03.001, 2008.

Andreae, M. O., Rosenfeld, D., Artaxo, P., Costa, A. A., Frank, G. P., Longo, K. M., and Silva-Dias, M. A. F.: Smoking rain clouds over the Amazon, Science, 303, 1337-1342, doi:10.1126/science.1092779, 2004.

Archer-Nicholls, S., Lowe, D., Darbyshire, E., Morgan, W. T., Bela, M. M., Pereira, G., Trembath, J., Kaiser, J. W., Longo,
K. M., Freitas, S. R., Coe, H., and McFiggans, G.: Characterising Brazilian biomass burning emissions using WRF-Chem with MOSAIC sectional aerosol, Geosci. Model Dev., 8, 549-577, doi:10.5194/gmd-8-549-2015, 2015.

Baklanov, A., Mahura, A., and Sokhi, R. S. (Eds.): Integrated Systems of Meso-Meteorological and Chemical Transport Models, Springer-Verlag, Berlin, Heidelberg, doi:10.1007/978-3-64213980-2, 2011.

Baklanov, A., Schlünzen, K., Suppan, P., Baldasano, J., Brunner, D., Aksoyoglu, S., Carmichael, G., Douros, J., Flemming, J., Forkel, R., Galmarini, S., Gauss, M., Grell, G., Hirtl, M., Joffre, S., Jorba, O., Kaas, E., Kaasik, M., Kallos, G., Kong, X., Korsholm, U., Kurganskiy, A., Kushta, J., Lohmann, U., Mahura, A., Manders-Groot, A., Maurizi, A., Moussiopoulos, N., Rao, S. T., Savage, N., Seigneur, C., Sokhi, R. S., Solazzo, E., Solomos, S., Sørensen, B., Tsegas, G., Vignati, E., Vogel, B., and Zhang, Y.: Online coupled regional meteorology chemistry models in Europe: current status and prospects, Atmos. Chem. Phys., 14, 317-398, doi:10.5194/acp-14-317-2014, 2014.

Barnard, J. C., Fast, J. D., Paredes-Miranda, G., Arnott, W. P., and Laskin, A.: Technical Note: Evaluation of the WRF-Chem "Aerosol Chemical to Aerosol Optical Properties" Module using data from the MILAGRO campaign, Atmos. Chem. Phys., 10, 7325-7340, doi:10.5194/acp-10-7325-2010, 2010.

Berg, L. K., Shrivastava, M., Easter, R. C., Fast, J. D., Chapman, E. G., Liu, Y., and Ferrare, R. A.: A new WRF-Chem treatment for studying regional-scale impacts of cloud processes on aerosol and trace gases in parameterized cumuli, Geosci. Model Dev., 8, 409-429, doi:10.5194/gmd-8-409-2015, 2015.

Bohren, C. Z. and Huffman, D. R.: Absorption and Scattering of Light by Small Particles, Wiley, New York, USA, 1983.

Bond, T. C. and Bergstrom, R. W.: Light absorption by carbonaceous particles: an investigative review, Aerosol Sci. Tech., 39 1-41, doi:10.1080/02786820500421521, 2006.

Bond, T. C., Habib, G., and Bergstrom, R. W.: Limitations in the enhancement of visible light absorption due to mixing state, $\mathrm{J}$. Geophys. Res., 111, D20211, doi:10.1029/2006JD007315, 2006.

Bond, T. C., Doherty, S. J., Fahey, D. W., Forster, P. M., Berntsen, T., Deangelo, B. J., Flanner, M. G., Ghan, S., Koch, D., Kinne, S., Kondo, Y., Quinn, P. K., Sarofim, M. C., Schultz, M. G., Schulz, M., Zhang, H., Zhang, S., Bellouin, N., Guttikunda, S. K., Hopke, P. K., Jacobson, M. Z., Klimont, Z., Lohmann, U., Schwarz, J. P., Shindell, D., Storelvmo, T., Warren, S. G., and Zender, C. S.: Bounding the role of black carbon in the climate system: a scientific assessment, J. Geophys. Res.Atmos., 11, 1-163, 2013.

Boucher, O., Randall, D., Artaxo, P., Bretherton, C., Feingold, G., Forster, P., Kerminen, V.-M., Kondo, Y., Liao, H., Lohmann, U., Rasch, P., Satheesh, S. K., Sherwood, S., Stevens, B., and Zhang, X. Y.: IPCC 2013, clouds and aerosols, in: Climate Change 2013: The Physical Science Basis, Contribution of Working Group I to the Fifth Assessment Report of the Intergovernmental Panel on Climate Change, edited by: Stocker, T. F., Qin, D., Plattner, G.-K., Tignor, M., Allen, S. K., Boschung, J., Nauels, A., Xia, Y., Bex, V., and Midgley, P. M., Cambridge University Press, Cambridge, UK and New York, NY, USA, 2013.

Chapman, E. G., Gustafson Jr., W. I., Easter, R. C., Barnard, J. C., Ghan, S. J., Pekour, M. S., and Fast, J. D.: Coupling aerosolcloud-radiative processes in the WRF-Chem model: Investigat- 
ing the radiative impact of elevated point sources, Atmos. Chem. Phys., 9, 945-964, doi:10.5194/acp-9-945-2009, 2009.

Chand, D., Wood, R., Anderson, T. L., Satheesh, S. K., and Charlson, R. J.: Satellite-derived direct radiative effect of aerosols dependent on cloud cover, Nat. Geosci., 2, 181-184, doi:10.1038/ngeo437, 2009.

Chen, Y.-C., Xue, L., Lebo, Z. J., Wang, H., Rasmussen, R. M., and Seinfeld, J. H.: A comprehensive numerical study of aerosolcloud-precipitation interactions in marine stratocumulus, Atmos. Chem. Phys., 11, 9749-9769, doi:10.5194/acp-11-9749-2011, 2011.

Cook, J. and Highwood, E. J.: Climate response to tropospheric absorbing aerosols in an intermediate general-circulation model, Q. J. Roy. Meteor. Soc., 130, 175-191, doi:10.1256/qj.03.64, 2004.

Donahue, N. M., Epstein, S. A., Pandis, S. N., and Robinson, A. L.: A two-dimensional volatility basis set: 1. organic-aerosol mixing thermodynamics, Atmos. Chem. Phys., 11, 3303-3318, doi:10.5194/acp-11-3303-2011, 2011.

Fan, J., Leung, L. R., Rosenfeld, D., Chen, Q., Li, Z., Zhang, J., and Yan, H.: Microphysical effects determine macrophysical response for aerosol impacts on deep convective clouds. P. Natl. Acad. Sci. USA, 110, E4581-E4590, doi:10.1073/pnas.1316830110, 2013.

Fast, J. D., Gustafson, W. I., Easter, R. C., Zaveri, R. A., Barnard, J. C., Chapman, E. G., Grell, G. A., and Peckham, S. E.: Evolution of ozone, particulates, and aerosol direct radiative forcing in the vicinity of Houston using a fully coupled meteorology-chemistry-aerosol model, J. Geophys. Res., 111, 129, doi:10.1029/2005JD006721, 2006.

Fast, J. D., Allan, J., Bahreini, R., Craven, J., Emmons, L., Ferrare, R., Hayes, P. L., Hodzic, A., Holloway, J., Hostetler, C., Jimenez, J. L., Jonsson, H., Liu, S., Liu, Y., Metcalf, A., Middlebrook, A., Nowak, J., Pekour, M., Perring, A., Russell, L., Sedlacek, A., Seinfeld, J., Setyan, A., Shilling, J., Shrivastava, M., Springston, S., Song, C., Subramanian, R., Taylor, J. W., Vinoj, V., Yang, Q., Zaveri, R. A., and Zhang, Q.: Modeling regional aerosol and aerosol precursor variability over California and its sensitivity to emissions and long-range transport during the 2010 CalNex and CARES campaigns, Atmos. Chem. Phys., 14, 10013-10060, doi:10.5194/acp-14-10013-2014, 2014.

Flemming, J., Peuch, V.-H., Engelen, R., and Kaiser, J. W.: A European global-to-regional air pollution forecasting system that combines modelling with satellite observations, EM Magazine, November 2013, 6-10, 2013.

Freitas, S. R., Longo, K. M., Chatfield, R., Latham, D., Silva Dias, M. A. F., Andreae, M. O., Prins, E., Santos, J. C., Gielow, R., and Carvalho Jr., J. A.: Including the sub-grid scale plume rise of vegetation fires in low resolution atmospheric transport models, Atmos. Chem. Phys., 7, 3385-3398, doi:10.5194/acp-7-3385-2007, 2007

Freitas, S. R., Longo, K. M., Alonso, M. F., Pirre, M., Marecal, V., Grell, G., Stockler, R., Mello, R. F., and Sánchez Gácita, M.: PREP-CHEM-SRC - 1.0: a preprocessor of trace gas and aerosol emission fields for regional and global atmospheric chemistry models, Geosci. Model Dev., 4, 419-433, doi:10.5194/gmd-4419-2011, 2011.

Ghan, S., Laulainen, N., Easter, R., Wagener, R., Nemesure, S., Chapman, E., Zhang, Y., and Leung, R.: Evaluation of aerosol di- rect radiative forcing in MIRAGE, J. Geophys. Res., 106, 52955316, 2001.

Ghan, S. J. and Easter, R. C.: Impact of cloud-borne aerosol representation on aerosol direct and indirect effects, Atmos. Chem. Phys., 6, 4163-4174, doi:10.5194/acp-6-4163-2006, 2006.

Ghan, S. J., Leung, L. R., Easter, R. C., and Abdul-Razzak, H.: Prediction of cloud droplet number in a general circulation model, J. Geophys. Res., 102, 21777-21794, 1997.

Ghan, S. J., Liu, X., Easter, R. C., Zaveri, R., Rasch, P. J., Yoon, J.H., and Eaton, B.: Toward a Minimal Representation of Aerosols in Climate Models: Comparative Decomposition of Aerosol Direct, Semidirect, and Indirect Radiative Forcing, J. Climate, 25, 6461-6476, doi:10.1175/JCLI-D-11-00650.1, 2012.

Grell, G. and Baklanov, A.: Integrated modelling for forecasting weather and air quality: a call for fully coupled approaches, Atmos. Environ., 45, 6845-6851, doi:10.1016/j.atmosenv.2011.01.017, 2011.

Grell, G. A. and Freitas, S. R.: A scale and aerosol aware stochastic convective parameterization for weather and air quality modeling, Atmos. Chem. Phys., 14, 5233-5250, doi:10.5194/acp-145233-2014, 2014.

Grell, G. A., Peckham, S. E., Schmitz, R., McKeen, S. A., Frost, G., Skamarock, W. C., and Eder, B.: Fully coupled "online" chemistry within the WRF model, Atmos. Environ., 39, 6957-6975, doi:10.1016/j.atmosenv.2005.04.027, 2005.

Grell, G., Freitas, S. R., Stuefer, M., and Fast, J.: Inclusion of biomass burning in WRF-Chem: impact of wildfires on weather forecasts, Atmos. Chem. Phys., 11, 5289-5303, doi:10.5194/acp11-5289-2011, 2011.

Hansen, J., Sato, M., and Ruedy, R.: Radiative forcing and climate response, J. Geophys. Res., 102, 6831-6864, 1997.

Haywood, J. and Boucher, O.: Estimates of the direct and indirect radiative forcing due to tropospheric aerosols: a review, Rev. Geophys., 38, 513, doi:10.1029/1999RG000078, 2000.

Haywood, J. M. and Shine, K. P.: The effect of anthropogenic sulfate and soot aerosol on the clear sky planetary radiation budget, Geophys. Res. Lett., 22, 603-606, 1995.

Hennigan, C. J., Westervelt, D. M., Riipinen, I., Engelhart, G. J., Lee, T., Collett, J. L., Pandis, S. N., Adams, P. J., and Robinson, A. L.: New particle formation and growth in biomass burning plumes: an important source of cloud condensation nuclei, Geophys. Res. Lett., 39, L09805, doi:10.1029/2012GL050930, 2012.

Heymsfield, A. J., Bansemer, A., Heymsfield, G., and Fierro, A. O.: Microphysics of Maritime Tropical Convective Updrafts at Temperatures from $-20^{\circ}$ to $-60^{\circ} \mathrm{C}$, J. Atmos. Sci., 66, 3530-3562, doi:10.1175/2009JAS3107.1, 2009.

Hollingsworth, A., Engelen, R. J., Benedetti, A., Dethof, A., Flemming, J., Kaiser, J. W., Morcrette, J.-J., Simmons, a. J., Textor, C., Boucher, O., Chevallier, F., Rayner, P., Elbern, H., Eskes, H., Granier, C., Peuch, V.-H., Rouil, L., and Schultz, M. G.: Toward a monitoring and forecasting system for atmospheric composition: the GEMS project, B. Am. Meteorol. Soc., 89, 1147-1164, doi:10.1175/2008BAMS2355.1, 2008.

Hong, S.-Y. and Dudhia, J.: Next-generation numerical weather prediction: bridging parameterization, explicit clouds, and large eddies, B. Am. Meteorol. Soc., 93, ES6-ES9, doi:10.1175/2011BAMS3224.1, 2012. 
Huffman, G. J., Adler, R. F., Morrissey, M. M., Bolvin, D. T., Curtis, S., Joyce, R., McGavock, B., and Susskind, J.: Global Precipitation at One-Degree Daily Resolution from Multisatellite Observations, J. Hydrometeorol., 2, 36-50, 2001.

Iacono, M. J., Mlawer, E. J., and Clough, S. A.: Impact of an improved longwave radiation model, RRTM, on the energy budget and thermodynamic properties of the NCAR community climate model, CCM3, J. Geophys. Res., 105, 14873-14890, 2000.

Janhäll, S., Andreae, M. O., and Pöschl, U.: Biomass burning aerosol emissions from vegetation fires: particle number and mass emission factors and size distributions, Atmos. Chem. Phys., 10, 1427-1439, doi:10.5194/acp-10-1427-2010, 2010.

Johnson, B. T.: The semidirect aerosol effect: comparison of a single-column model with large eddy simulation for marine stratocumulus, B. Am. Meteorol. Soc., 18, 119-130, 2004.

Johnson, B. T., Shine, K. P., and Forster, P. M.: The semidirect aerosol effect: impact of absorbing aerosols on marine stratocumulus, Q. J. Roy. Meteor. Soc., 130, 1407-1422, doi:10.1256/qj.03.61, 2004

Jolleys, M. D., Coe, H., McFiggans, G., Capes, G., Allan, J. D., Crosier, J., Williams, P. I., Allen, G., Bower, K. N., Jimenez, J. L., Russell, L. M., Grutter, M., and Baumgardner, D.: Characterizing the aging of biomass burning organic aerosol by use of mixing ratios: a meta-analysis of four regions, Environ. Sci. Technol., 46, 13093-13102, doi:10.1021/es302386v, 2012.

Koch, D. and Del Genio, A. D.: Black carbon semi-direct effects on cloud cover: review and synthesis, Atmos. Chem. Phys., 10, 7685-7696, doi:10.5194/acp-10-7685-2010, 2010.

Kodros, J. K., Scott, C. E., Farina, S. C., Lee, Y. H., L'Orange, C., Volckens, J., and Pierce, J. R.: Uncertainties in global aerosols and climate effects due to biofuel emissions, Atmos. Chem. Phys., 15, 8577-8596, doi:10.5194/acp-15-8577-2015, 2015.

Köhler, H.: The nucleus in and the growth of hygroscopic droplets, T. Faraday Soc., 32, 1152-1161, doi:10.1039/TF9363201152, 1936.

Kolusu, S. R., Marsham, J. H., Mulcahy, J., Johnson, B., Dunning, C., Bush, M., and Spracklen, D. V.: Impacts of Amazonia biomass burning aerosols assessed from short-range weather forecasts, Atmos. Chem. Phys., 15, 12251-12266, doi:10.5194/acp-15-12251-2015, 2015.

Lohmann, U. and Feichter, J.: Global indirect aerosol effects: a review, Atmos. Chem. Phys., 5, 715-737, doi:10.5194/acp-5-7152005, 2005.

Lohmann, U. and Ferrachat, S.: Impact of parametric uncertainties on the present-day climate and on the anthropogenic aerosol effect, Atmos. Chem. Phys., 10, 11373-11383, doi:10.5194/acp10-11373-2010, 2010.

Longo, K. M., Freitas, S. R., Andreae, M. O., Setzer, A., Prins, E., and Artaxo, P.: The Coupled Aerosol and Tracer Transport model to the Brazilian developments on the Regional Atmospheric Modeling System (CATT-BRAMS) - Part 2: Model sensitivity to the biomass burning inventories, Atmos. Chem. Phys., 10, 5785-5795, doi:10.5194/acp-10-5785-2010, 2010.

Martin, S. T., Andreae, M. O., Artaxo, P., Baumgardner, D., Chen, Q., Goldstein, A. H., Guenther, A., Heald, C. L., Bracero, O. L. M., Mcmurry, P. H., Pauliquevis, T., Pöschl, U., Prather, K. A., Roberts, G. C., Saleska, S. R., Silva-Dias, M. A., Spracklen, D. V., and Swietlicki, E. T.: Sources and proper- ties of amazonian aerosol particles, Rev. Geophys., 48, 1-42, doi:10.1029/2008RG000280, 2010.

Matsui, H., Koike, M., Kondo, Y., Moteki, N., Fast, J. D., and Zaveri, R. A.: Development and validation of a black carbon mixing state resolved three-dimensional model: aging processes and radiative impact, J. Geophys. Res.-Atmos., 118, 2304-2326, doi:10.1029/2012JD018446, 2013.

McFiggans, G., Artaxo, P., Baltensperger, U., Coe, H., Facchini, M. C., Feingold, G., Fuzzi, S., Gysel, M., Laaksonen, A., Lohmann, U., Mentel, T. F., Murphy, D. M., O’Dowd, C. D., Snider, J. R., and Weingartner, E.: The effect of physical and chemical aerosol properties on warm cloud droplet activation, Atmos. Chem. Phys., 6, 2593-2649, doi:10.5194/acp-6-2593-2006, 2006.

Mlawer, E. J., Taubman, S. J., Brown, P. D., Iacono, M. J., and Clough, S. A.: Radiative transfer for inhomogeneous atmospheres: RRTM, a validated correlated-k model for the longwave, J. Geophys. Res., 102, 16663-16682, doi:10.1029/97JD00237, 1997.

Morrison, H., Curry, J. A., and Khvorostyanov, V. I.: A new doublemoment microphysics parameterization for application in cloud and climate models, Part I: Description, J. Atmos. Sci., 62, 16651677, doi:10.1175/JAS3446.1, 2005.

Morrison, H., Thompson, G., and Tatarskii, V.: Impact of cloud microphysics on the development of trailing stratiform precipitation in a simulated squall line: comparison of one- and two-moment schemes, Mon. Weather Rev., 137, 991-1007, doi:10.1175/2008MWR2556.1, 2009.

Pöschl, U., Martin, S. T., Sinha, B., Chen, Q., Gunthe, S. S., Huffman, J. A, Borrmann, S., Farmer, D. K., Garland, R. M., Helas, G., Jimenez, J. L., King, S. M., Manzi, A, Mikhailov, E., Pauliquevis, T., Petters, M. D., Prenni, A. J., Roldin, P., Rose, D., Schneider, J., Su, H., Zorn, S. R., Artaxo, P., and Andreae, M. O.: Rainforest aerosols as biogenic nuclei of clouds and precipitation in the Amazon, Science, 329, 1513-1516, doi:10.1126/science.1191056, 2010.

Possner, A., Zubler, E., Lohmann, U., and Schär, C.: Realcase simulations of aerosol-cloud interactions in ship tracks over the Bay of Biscay, Atmos. Chem. Phys., 15, 2185-2201, doi:10.5194/acp-15-2185-2015, 2015.

Reid, J. S., Koppmann, R., Eck, T. F., and Eleuterio, D. P.: A review of biomass burning emissions part II: intensive physical properties of biomass burning particles, Atmos. Chem. Phys., 5, 799 825, doi:10.5194/acp-5-799-2005, 2005a.

Reid, J. S., Eck, T. F., Christopher, S. A., Koppmann, R., Dubovik, O., Eleuterio, D. P., Holben, B. N., Reid, E. A., and Zhang, J.: A review of biomass burning emissions part III: intensive optical properties of biomass burning particles, Atmos. Chem. Phys., 5, 827-849, doi:10.5194/acp-5-827-2005, 2005 b.

Romakkaniemi, S., McFiggans, G., Bower, K. N., Brown, P., Coe, H., and Choularton, T. W.: A comparison between trajectory ensemble and adiabatic parcel modeled cloud properties and evaluation against airborne measurements, J. Geophys. Res.Atmos., 114, D06214, doi:10.1029/2008JD011286, 2009.

Rosenfeld, D., Lohmann, U., Raga, G. B., O’Dowd, C. D., Kulmala, M., Fuzzi, S., Reissell, A., and Andreae, M. O.: Flood or drought: how do aerosols affect precipitation?, Science, 321, 1309-13, doi:10.1126/science.1160606, 2008.

Saide, P. E., Spak, S. N., Carmichael, G. R., Mena-Carrasco, M. A., Yang, Q., Howell, S., Leon, D. C., Snider, J. R., Bandy, A. 
R., Collett, J. L., Benedict, K. B., de Szoeke, S. P., Hawkins, L. N., Allen, G., Crawford, I., Crosier, J., and Springston, S. R.: Evaluating WRF-Chem aerosol indirect effects in Southeast Pacific marine stratocumulus during VOCALS-REx, Atmos. Chem. Phys., 12, 3045-3064, doi:10.5194/acp-12-3045-2012, 2012.

Sakaeda, N., Wood, R., and Rasch, P. J.: Direct and semidirect aerosol effects of southern African biomass burning aerosol, J. Geophys. Res., 116, D12205, doi:10.1029/2010JD015540, 2011.

Segal, Y., Pinsky, M., Khain, A., and Erlick, C.: Thermodynamic factors influencing bimodal spectrum formation in cumulus clouds, Atmos. Res., 66, 43-64, doi:10.1016/S01698095(02)00172-2, 2003.

Shrivastava, M., Fast, J., Easter, R., Gustafson Jr., W. I., Zaveri, R. A., Jimenez, J. L., Saide, P., and Hodzic, A.: Modeling organic aerosols in a megacity: comparison of simple and complex representations of the volatility basis set approach, Atmos. Chem. Phys., 11, 6639-6662, doi:10.5194/acp-11-6639-2011, 2011.

Shrivastava, M., Berg, L. K., Fast, J. D., Easter, R. C., Laskin, A., Chapman, E. G., Jr, W. I. G., Liu, Y., and Berkowitz, C. M.: modelling aerosols and their interactions with shallow cumuli during the 2007 CHAPS field study, J. Geophys. Res.-Atmos., 118, 1343-1360, doi:10.1029/2012JD018218, 2013.

Simpson, E., Connolly, P., and McFiggans, G.: An investigation into the performance of four cloud droplet activation parameterisations, Geosci. Model Dev., 7, 1535-1542, doi:10.5194/gmd-71535-2014, 2014.

Tosca, M. G., Randerson, J. T., and Zender, C. S.: Global impact of smoke aerosols from landscape fires on climate and the Hadley circulation, Atmos. Chem. Phys., 13, 5227-5241, doi:10.5194/acp-13-5227-2013, 2013.

Twomey, S.: Pollution and the planetary albedo, Atmos. Environ., 8, 1251-1256, 1974.

Wu, L., Su, H., and Jiang, J. H.: Regional simulations of deep convection and biomass burning over South America: 1. model evaluations using multiple satellite data sets, J. Geophys. Res., 116, D17208, doi:10.1029/2011JD016106, 2011a.

Wu, L., Su, H., and Jiang, J. H.: Regional simulations of deep convection and biomass burning over South America: 2. biomass burning aerosol effects on clouds and precipitation, J. Geophys. Res., 116, D17209, doi:10.1029/2011JD016106, 2011 b.
Yang, Q., W. I. Gustafson Jr., Fast, J. D., Wang, H., Easter, R. C., Morrison, H., Lee, Y.-N., Chapman, E. G., Spak, S. N., and Mena-Carrasco, M. A.: Assessing regional scale predictions of aerosols, marine stratocumulus, and their interactions during VOCALS-REx using WRF-Chem, Atmos. Chem. Phys., 11, 11951-11975, doi:10.5194/acp-11-11951-2011, 2011.

Yang, Q., Easter, R. C., Campuzano-jost, P., Jimenez, J. L., Fast, J. D., Shrivastava, M. B., Singh, B., Morrison, H., Fan, J., and Ziegler, C. L.: Aerosol transport and wet scavenging in deep convective clouds: A case study and model evaluation using a multiple passive tracer analysis approach, J. Geophys. Res.Atmos., 120, 8448-8468, doi:10.1002/2015JD023647, 2015.

Zaveri, R. A. and Peters, L. K.: A new lumped structure photochemical mechanism for large-scale applications, J. Geophys. Res., 104, 30387-30415, 1999.

Zaveri, R. A., Easter, R. C., Fast, J. D., and Peters, L. K.: Model for simulating aerosol interactions and chemistry (MOSAIC), J. Geophys. Res., 113, D132024, doi:10.1029/2007JD008782, 2008.

Zhang, F., Wang, J., Ichoku, C., Hyer, E. J., Yang, Z., Ge, C., Su, S., Zhang, X., Kondragunta, S., Kaiser, J. W., Wiedinmyer, C., and da Silva, A.: Sensitivity of mesoscale modelling of smoke direct radiative effect to the emission inventory: a case study in northern sub-Saharan African region, Environ. Res. Lett., 9, 075002, doi:10.1088/1748-9326/9/7/075002, 2014.

Zhang, Y., Fu, R., Yu, H., Dickinson, R. E., Juarez, R. N., Chin, M., and Wang, H.: A regional climate model study of how biomass burning aerosol impacts land-atmosphere interactions over the Amazon, J. Geophys. Res., 113, D14S15, doi:10.1029/2007JD009449, 2008.

Zhao, C., Liu, X., Ruby Leung, L., and Hagos, S.: Radiative impact of mineral dust on monsoon precipitation variability over West Africa, Atmos. Chem. Phys., 11, 1879-1893, doi:10.5194/acp11-1879-2011, 2011. 